\title{
Is It Time to Let Meritocracy Go?
}

Despite meritocratic claims of equal opportunity, official statistics released by the Ministry of Education, Singapore, reveal that a large segment of the Malay population has sustained the lowest academic achievement from 1987 to 2011. This statistical representation raises the possibility of a politically induced, systemic inequality as a point of investigation.

To investigate this seeming contradiction between the rhetoric and practice of equal educational opportunity, Nadira Talib analyses education policies by drawing on a synthesis of philosophical perspectives and critical discourse analysis as a way of making explicit how the historical constitution of the learner is linked to the legitimisation of inequitable education policies that favour corporatist practices. By making explicit how the underlying assumption of the policy 'logic' that increasing expenditure on 'talents' must necessarily involve the increasing welfare of everybody is both unsubstantiated and arbitrary, the book presents a moral political problem in demonstrating how education policies are unfounded and unsupported through the idea of meritocracy.

Nadira Talib holds a Ph.D. from The University of Queensland, Australia. She focuses on developing a method of synthesising philosophical deliberations with discourse analysis in analysing social policy. In questioning the systems that separate and divide human beings one from another, her work centres on examining how adhering to the perceived demands of surrealistic political economies is imbricated within the relations of morality and ethics. Her publications are featured in ScienceDaily and in an editorial review of 'The Top 100 Cited Discourse Studies' in the subject area of 'linguistics and language', in the years 2015-2019. 


\section{Routledge Critical Studies in Asian Education}

English Language Teacher Preparation in Asia

Policy, Research and Practice

Edited by Subhan Zein and Richmond Stroupe

Lesson Study and Schools as Learning Communities

Asian School Reform in Theory and Practice

Edited by Atsushi Tsukui and Masatsugu Murase

The Asian EFL Classroom

Issues, Challenges and Future Expectations

Edited by Soo-Ok Kwen and Bernard Spolsky

Teacher Education for English as a Lingua Franca

Perspectives from Indonesia

Edited by Subhan Zein

The Governance and Management of Universities in Asia

Global Influences and Local Responses

Chang Da Wan, Molly N.N. Lee, and Hoe Yeong Loke

Building Teacher Capacity in Vietnamese English Language Teaching Research, Policy and Practice

Edited by Van Canh Le, Hoa Thi Mai Nguyen, Thi Thuy Minh Nguyen, Roger Barnard

Is it Time to Let Meritocracy Go?

Examining the Case of Singapore

Nadira Talib

For more information about this series, please visit: www.routledge.com/RoutledgeCritical-Studies-in-Asian-Education/book-series/RCSAE 


\section{Is It Time to Let Meritocracy Go?}

Examining the Case of Singapore

Nadira Talib 
First published 2021

by Routledge

2 Park Square, Milton Park, Abingdon, Oxon OX14 4RN

and by Routledge

52 Vanderbilt Avenue, New York, NY 10017

Routledge is an imprint of the Taylor \& Francis Group, an informa business

(C) 2021 Nadira Talib

The right of Nadira Talib to be identified as author of this work has been asserted by her in accordance with sections 77 and 78 of the Copyright, Designs and Patents Act 1988.

All rights reserved. No part of this book may be reprinted or reproduced or utilised in any form or by any electronic, mechanical, or other means, now known or hereafter invented, including photocopying and recording, or in any information storage or retrieval system, without permission in writing from the publishers.

Trademark notice: Product or corporate names may be trademarks or registered trademarks, and are used only for identification and explanation without intent to infringe.

British Library Cataloguing-in-Publication Data

A catalogue record for this book is available from the British Library

Library of Congress Cataloging-in-Publication Data

Names: Talib, Nadira, author.

Title: Is it time to let meritocracy go? : examining the case

of Singapore / Nadira Talib.

Description: Abingdon, Oxon ; New York, NY : Routledge, 2020. |

Series: Routledge critical studies in Asian education |

Includes bibliographical references and index.

Identifiers: LCCN 2020006037 (print) | LCCN 2020006038 (ebook) |

ISBN 9781138320000 (hardback) | ISBN 9780367502874 (paperback) |

ISBN 9780429453625 (ebook)

Subjects: LCSH: Educational equalization--Singapore. |

Merit (Ethics)--Singapore. | Discrimination in education--Singapore. |

Academic achievement--Singapore. | Education and state--Singapore.

Classification: LCC LC213.3.S5 T35 2020 (print) |

LCC LC213.3.S5 (ebook) | DDC 379.2/6095957--dc23

LC record available at https://lccn.loc.gov/2020006037

LC ebook record available at https://lccn.loc.gov/2020006038

ISBN: 978-1-138-32000-0 (hbk)

ISBN: 978-0-429-45362-5 (ebk)

Typeset in Galliard

by Taylor \& Francis Books 


\section{Contents}

Preface viii

Acknowledgments $\quad \mathrm{x}$

1 Introduction: Questions and themes 1

2 Creating the conditions for division and structural inequality: The $\begin{array}{ll}\text { human being as a historical construct } & 20\end{array}$

3 Using genealogy and ethics to investigate the conditioning of human beings into moral subjects who desire more

4 Micro-meso-macro movements: A multi-level critical discourse analysis framework to examine the value of truth 63

5 Theme 1: Metaphorical realism $\quad 88$

6 Theme 2: De/regulation 119

7 Theme 3: Political economies of surrealism 134

$8 \quad$ Inequality as meritocracy $\quad 164$

$\begin{array}{lr}\text { Policy reports and speeches } & 188\end{array}$

$\begin{array}{ll}\text { References } & 195\end{array}$

$\begin{array}{ll}\text { Index } & 208\end{array}$ 


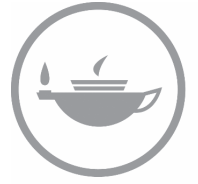
Taylor \& Francis Taylor \& Francis Group http://taylorandfrancis.com 
In order to treat people the way they are being treated we have to commodify the individual. So the individual himself or herself needs to become a commodity, which means that our value is based simply on what we produce or what we acquire, but not actually who we are. It's not based on just our very existence as human beings. A way that you attain value is to contribute, so who you are as a human being, in your very existence, is insufficient to give you value. You have to be producing something. People are desperately trying to make themselves useful totally ignoring who they are. It's the foundation of most chronic illnesses in our society because of the mind/body entity. But the very ideology that dying people are useless, or that anybody is useless, is a reflection of the capitalist idea that people are only useful when they produce.

Gabor Maté, 2012, 'What Promotes Positive Health' (https://www.youtube.com/watch?v=rYbeyU3pQvI) 


\section{Preface}

Within a multi-ethnic society that could not afford ethnic discrimination, the government of Singapore sought to enshrine meritocracy as a core value and promote advancement by merit (Rahim, 1998, p. 5). Driven by economic imperatives and efficiency, streaming was introduced as a policy in 1979 and an explicit form of structuration became widely practised in schools. While official discourse seeks to defend streaming as central to achieving success and reducing attrition rates, statistics released by the Ministry of Education reveal that a large segment of the Malay population has sustained the lowest academic achievement from 1987 to 2011 (MOE, 1997; 2012), despite meritocratic claims of equal opportunity. In order to understand how the inconsistencies between educational meritocracy and inequity have been made manifest, this monograph analyses education policies by drawing on a synthesis of philosophical perspectives and critical discourse analysis as a way of making explicit how the historical constitution of the learner is linked to the legitimisation of inequitable education policies that favour corporatist practices.

Specifically, to understand how we have been trapped in our own history (Foucault, 1982a, p. 780), where the ideology that economic growth is the (only) way forward has been taken as self-evident, and to answer questions about inequality in Singapore (Goh, 2016), this monograph focuses on how historically, education policies contribute to systematically engineering consent for inequality within a meritocratic system. In order to know the truth of this particular dimension, the book turns to a philosophical-analytical method to examine the conditions under which pursuing the finite-driven goal of economic growth has fuelled inequality. It is not the purpose of this monograph to trace the movement of policy discourse till the present, but rather to show that inequality has deep roots in history, through analysing the evolution of education policies between 1979 and 2019. In order to interpret the contemporary state of systematic inequality, there is a need to trace its historical and evolutionary development and construction (Garrity, 2010, p. 203). Policies of the past can influence and interfere with the proposals and propositions of future policies as long as one is not aware of this past (cf. Bohm, 2005, p. 257). This is not to say that past 'explains' or determines the present state of inequality, but in showing 'how' it may have happened, this monograph describes the chain of events of which it seemed to be a part and provides empirical guidance regarding the genesis and prevalence of structural inequality (cf. Watts, 1951, p. 126). 
The analysis highlights that value judgments are continually at work in policy discourse and that despite the strong discourse of meritocracy that the Singapore education system promotes, the eternally recurring metaphors of flexibility, diversity, choice, and opportunity - as 'engines' of neo-liberal discourse - provide the necessary basis from which to rationalise unequal structural reforms as a desirable form of ethical practice to pursue economic growth. By tracing and examining these metaphors, the policy texts reveal a particular emphasis on the simultaneous processes of truth production and reproduction, supporting and supported by means and modes of value distribution, in the form of meritocratic inequality. More importantly, by making explicit how the underlying assumption of the policy 'logic' that increasing expenditure on 'talents' must necessarily involve the increasing welfare of everybody is both unsubstantiated and arbitrary, the monograph presents a moral political problem in demonstrating how education policies are unfounded and unsupported through the idea of meritocracy. If this is true, meritocracy can exist only as an idea, an idea which can never be realised in practical life. Is it time to let meritocracy go? 


\section{Acknowledgments}

This monograph is derived in part from the following articles:

Talib, N. (25 June 2019). Creating the conditions for human division and structural inequality: The foundation of Singapore's education policy. Journal of Language and Politics, 18(5), 739-759. Available online: https://benjamins.com/catalog/ jlp.18070.tal. http://doi.org/10.1075/jlp.18070.tal

Talib, N. \& Fitzgerald, R. (3 January2018). Putting philosophy back to work in Critical Discourse Analysis. Special issue on ethics of critical discourse studies. Critical Discourse Studies, 15(2), 123-139. Available online: https://www.tandfonline.com/ doi/abs/10.1080/17405904.2017.1421242?journalCode=rcds20. https://doi. org/10.1080/17405904.2017.1421242

Talib, N. \& Fitzgerald, R. (17 May 2016). Micro-meso-macro movements: A multilevel critical discourse analysis framework to examine metaphors and the value of truth in policy texts. Critical Discourse Studies, 13(5), 531-547. Available online: https://www.tandfonline.com/doi/abs/10.1080/17405904.2016.1182932. https://doi.org/10.1080/17405904.2016.1182932

Talib, N. \& Fitzgerald, R. (23 April 2015). Inequality as meritocracy: The use of the metaphor of diversity and the value of inequality within Singapore's meritocratic education system. Critical Discourse Studies, 12(4), 445-462. Available online: https://www.tandfonline.com/doi/abs/10.1080/17405904.2015.1034740. https://doi.org/10.1080/17405904.2015.1034740 


\title{
1 Introduction
}

\author{
Questions and themes
}

\section{Overview}

While Singapore's education system claims to implement meritocratic ideals, official statistics indicate that Malay students in Singapore have been underperforming when compared to other ethnic groups (MOE, 2012). This statistical representation raises the possibility of a politically induced, systemic inequality as a point of investigation. In order to interpret the contemporary state of inequality, there is a need to trace its historical and evolutionary development and construction (Garrity, 2010, p. 203). Towards this end, this research is both an investigation into how policy discourses manage the contradictions inherent in Singapore's streaming ${ }^{1}$ system, and at the same time it is also, fundamentally, an investigation into the practice and advancement of critical discourse analysis $(\mathrm{CDA})^{2}$ in examining inequality.

The focus of this research is primarily theoretical and methodological, articulated through a concern with the interface between theoretical concepts and methodological principles in interpreting empirical material. In doing so, it presents detailed methods for constructing a flexible philosophical-analytical model through which to apply the analytic principles of CDA for the interpretation of policy texts, thus developing CDA as a theory and method to enhance its capacity to tackle inequality. This philosophical-analytical framework developed through the analysis makes use of Foucault's work on archaeology, genealogy, and ethics, and Nietzsche's work on valuation.

This introductory chapter presents an overview of the history of Singapore's education system and the course of events that precipitated streaming in schools, how this policy has been supported by the media, and the outcomes and critiques of the streaming policy. The following sections will outline the research trajectory, briefly summarise the significance of the research and its contribution to the field, and, finally, provide an overview of the structure of the rest of the book that highlights the theoretical-methodological coordinates of this investigation. 


\section{Introduction}

\section{Making sense of Singapore's education policies}

The Report on the Ministry of Education 1978 (MOE, 1979a) was the first to propose an explicit form of ability-based streaming which heralded the introduction of the 'New Education System' (NES) (Barr \& Skrbiš, 2008, p. 114; Soon, 1988, p. 1). This major policy initiative, which has since then profoundly altered the shape of Singapore's education system, is underpinned by the 'fundamental belief that ability grouping is responsive to learners' diverse capacities and would 'better fulfil his (a student's) innate potential' ( $\mathrm{Ng}, 2008 \mathrm{a}, \mathrm{n} . \mathrm{p}$.$) .$ Working on the fundamental principle of meritocracy, the system is designed to promote and explicitly claims to reward those who work hard (Wong, 2000, n. p.) through a 'streaming' mechanism in which different abilities and capacities can be identified, nurtured, and appropriately allocated for the benefit of a growing Singapore populace. Subsequent policies and policy adjustments in 1987, 1991, 2002, 2003, 2006, 2008, 2012a, and 2019 have adapted and reinforced the 1979 policy based on meritocratic principles. Within this frame of meritocracy, streaming is represented as an increasingly necessary driver for securing Singapore's economic strength.

While a 'horizontal' form of diversity (Archer, 2007, p. 639) featured prominently in the 1979 and 1991 MOE reports, which recommended a range of strategies designed to address the presumable absorption capacities of 'slow' learners, subsequent policies published in 1987, 2002, 2006, and 2012a focus on a 'vertical' form of diversity (Archer, 2007, p. 639). This form of diversity provides exclusive opportunities for greater diversification in the system to nurture and prepare talents for an era of what Gopinathan (2007, pp. 61-62) refers to as 'innovation-driven growth'. Using carefully constructed arguments, the original and successive policy discourses draw upon and weave together different discursive formations that are brought forward under the rubric of meritocracy. While the discourse of meritocracy is a fundamental part of official rhetoric, the shifts in emphasis within these policies that aim to identity and groom talents contradict meritocratic principles. Indeed, it is the coexistence of these apparently contradictory strands that, in the view of this research, constitutes much of what is distinctive about current education policy and practice in Singapore. This study seeks to explore and account for this hybridity. It is particularly interested in what is seen as an attempt by policymakers to broaden opportunities for students who have 'talent' as defined by policy while at the same time claiming meritocratic ideals.

Based on a historical analysis of what might happen to Britain between 1870 and 2033, in 'The rise of meritocracy' (1958), Michael Young used the word 'meritocracy' in a pejorative sense and a term of disapprobation, arguing that the test-based system of advancement emerging in post-war Britain which appeared to provide opportunity for all was actually a coercive apparatus of the state through which a particular class maintains control and reproduces itself. Young himself was profoundly critical of the development he identified, and his futuristic satire was meant to be a warning of the folly of meritocratic life that polarises society and 
encourages the belief that one's advancement is a result of one's own merits (Sen, 2000 , p. 7). Lacking access to schools with optimal resources, children from less privileged backgrounds consistently fared poorly in the 11-plus exam - the test given to children after sixth grade that largely predetermined their professions. As a consequence, the disadvantaged remained at the bottom of the social ladder, their underperformance used to validate the status quo. With the insistence on meritocracy, the underprivileged class masses become increasingly disfranchised and deprived by educational selection; they no longer have their own people to act in their interests and bring about specific outcomes. Young's apocalyptic vision, which ends in an imagined final revolt and countermovement against meritocracy in 2033, was credited with leading to the dissolution of the 11-plus in Britain (Fox, 2002, n.p.).

Meritocracy is a key principle of educational governance in Singapore's streaming system and is defined as 'equal opportunities for each student to learn and to achieve his or her potential' (Wong, 2000, n.p.). Through a detailed examination of recent educational policy discourses, this research seeks to explore how these enduring meritocratic principles and procedures are increasingly forced to coexist with broader notions of talent opportunities at the expense of ensuring equality of outcomes. The following section provides some historical context and a brief leadup to the Goh report.

\section{History of Singapore's education system and the Goh report}

Formerly a British colony, Singapore attained full internal self-government in 1959, and became part of Malaysia until 1965 (Betts, 1975, p. 149). Since gaining independence in 1965, it has been under the purview of the People's Action Party (PAP) government. In the 1950s and 1960s, 'the Singapore educational sectors inherited from the British an ethno-linguistically divided, under-resourced system incapable of meeting the twin demands of unifying a pluralistic society (i.e. nation building) or match [sic] the evolving needs of a modern economy' (Gopinathan, 1995, 1997 as cited in Gopinathan, 2006, p. 296). Rather than abandoning colonial legal and legislative traditions, the government built upon these structures and constructed a centralised system of education to forge and articulate a Singaporean identity (Chia, 2011, p. 22) and promote social cohesion among the different ethnic communities. The system had a central focus on using both English and the Mother Tongue to produce a competent workforce through systematic skill formation strategies (Gopinathan, 2006, p. 296). More importantly, within a multi-ethnic society that could not afford ethnic discrimination, the government sought to enshrine meritocracy as a core value and promote advancement by merit (Rahim, 1998, p. 5).

After Singapore gained independence, the government started to study various aspects of education. Major weaknesses were identified in the late 1960s and 1970s ( Ng, 2008b, p. 114). Of major concern were the 'problems of ineffective curriculum, low literacy levels and high resource wastage in the system' $(\mathrm{Ng}$, 2008 b, p. 114). Recommendations of the review of the educational system resulted in the 1979 Goh report, from which various education policies emanate, 


\section{Introduction}

including an early streaming system in schools and vocational education (Rahim, 1998 , p. 121). It was not until the introduction of streaming as a policy and as an efficient allocating mechanism in 1979 that any form of explicit student division was widely practised in schools. The 1970s and 1980s saw the development of an efficiency-driven system based on the tracking and promotion of academic or cognitive achievement (Gopinathan, 2006, p. 299).

Dr Goh Keng Swee presented the 'Goh Report' in February 1979. It was an assessment of MOE's problems, and introduced the 'New Education System' (NES) (Barr \& Skrbiš, 2008, p. 114; Soon, 1988, p. 1), which used streaming to provide a curriculum that would respond to students of varied abilities and backgrounds so as to reduce 'educational wastage, low literacy and non-attainment of effective bilingualism' (MOE, 1979a, pp. 3-1, 3-4). The solution was to stream students to suit slow, average, above average and outstanding learners based on their school performance and intelligence tests (Mauzy \& Milne, 2002, p. 104).

Inconsistent with meritocratic claims of 'equal opportunities' (Wong, 2000, n.p.), streaming was introduced to redress the imbalance of enrolment in academic and technical streams and to ensure that the country possessed a sufficient pool of technically skilled local workers to serve the broader goals of economic development and sustainable growth (Goh \& Gopinathan, 2008, p. 27; Lee et al., 2008, pp. 3-5; Rahim, 1998, p. 124). This gap was initially emphasised in a ministerial report in 1968 and radical changes were introduced in the field of technical education from 1969 to prepare the young to take up new economic activities that were being generated by an expanding manufacturing sector in the 1970s (Lee et al., 2008, p. 3). In conjunction with the Goh report, in 1979, the Vocational and Industrial Training Board (VITB) Act came into existence to meet the growing need for technical and skilled manpower. Through this, education becomes the social engineering process for national productivity within the context of educational meritocracy to meet industrial demands. Herein lies the contradiction between the discourses of meritocracy and streaming, and the efforts of the state to manage one in conjunction with the other. Established through the amalgamation of the Industrial Training Board (ITB) and Adult Education Board (AEB), the VITB's primary purpose was to provide an alternative for adults who did not continue their education up to the GCE ' $\mathrm{O}$ '3 or ' $\mathrm{A}^{4}$ level $(\mathrm{Ng}, 2008 \mathrm{c}$, p. 54). A review in the late 1980s led to the establishment of the Institute of Technical Education (ITE) to provide post-secondary training (Gopinathan, 1999, p. 298). As Lee Yock Suan, former Minister for Education, argued in June 1994:

Singapore will be poorer if everyone aspires to and gets only academic qualifications but nobody knows how to fix a TV set, a machine tool or a process plant. We need a world-class workforce with a wide variety of knowledge of skills to achieve a world-class standard of living.

(Quoted in Goh \& Gopinathan, 2008, p. 27)

Streaming then becomes an instrument for determining one's precise place in a school hierarchy, ostensibly in return for greater economic successes (Barr \& 
Skrbiš, 2008, p. 181). As Rahim (1998, p. 124) points out: streaming facilitates the 'channelling of students from the various educational streams eventually into the varying levels of the occupational hierarchy'. As such, in defending the cause for streaming as being in everyone's best interests, the media published statements by a succession of Ministers for Education who cited strong outcomes by international standards even for 'weaker' students and low levels of attrition up to postsecondary education (Ng, 2008a, n.p.; Shanmugaratnam, 2004, n.p.). However, the official justification for streaming in the state media continues to be grounded in customising pupils' education according to their abilities (Shanmugaratnam, 2004 , n.p.). In justifying pro-national and economic interests, the concept and practice of meritocracy is then unstable. The twin principles of meritocracy as equal opportunity and the pursuit of economic interest are potentially contradictory. At one level streaming is justified in terms of economic development. At another level it is justified in terms of equality of opportunity depending on abilities, which are conceived of as inherent, and not socially or culturally shaped. The central research inquiry revolves around the understanding of how meritocracy is negotiated amidst economic imperatives.

\section{Parallel media and official discourse on the 1979 MOE report}

Education policies are justified through both education policies and the media. Specifically, justifications for streaming in reducing educational wastage, catering to different abilities of students, and minimising failures and damage to self-esteem are three key elements of the 1979 MOE report that have been extended to and expressed in media discourse. In particular, how failures are constructed is discursively aligned with, and mirrors, the 1979 report. Given that official justifications in the media are drawn from the policy, this extension establishes the importance of examining how policy discourse legitimises streaming. Within a state-controlled media system, the media in Singapore can be taken to 'reproduce' the state discourse, as the role of the press is to support rather than to challenge government policies (Holaday \& Kuo, 1993 as cited in Hao, 1996, p. 112).

In reviewing the primary school streaming system, Members of Parliament called on then Education Minister Teo Chee Hean to rethink some of the policies. His response to their concerns was published in the Straits Times, in an article titled, 'Education System Caters to All Abilities' on 22 May 2002. Meritocracy and appropriate opportunities for all codifies the defence for streaming by Rear-Admiral Teo, who places the institutional practice at the centre of educational reform by arguing that catering to the ability of the child is imperative (Teo, 2002a, n.p.) He argues that a standard, albeit relatively 'more-demanding', curriculum could potentially cause students who consistently fail to suffer from low self-esteem. Going by the philosophy that children learn differently, he maintains that streaming is 'the correct approach', as it helps each child to meet his or her potential through customised programmes made to ensure their academic success and consequently, a high possibility of employment (Teo, 2002a, n.p., italics added). 


\section{Introduction}

In a subsequent article 'Meeting Different Needs' published on 26 November 2002 in the Straits Times, Teo continues his defence of a more diversified education system, explaining the changes recommended by the review committee on upper secondary and junior college education. Teo's defence highlights two guiding principles: 'meritocracy' and 'the need for students who have benefited from the best the system had to offer to recognise their obligation to the country' (Teo, 2002b, n.p.). These two key forms of rhetoric within the official discourse are used to bolt together conflicting and contrasting motivations and interests. This rhetoric had a self-contradictory proposition: while meritocracy dictates equality of access for everyone, it does in fact recognise that a particular section of the student population receives privileged access to specialised programmes (Teo, 2002b, n.p). This official prescription that subscribes to curriculum customisation is in fundamental conflict with the meritocratic dictum which purports 'equal opportunities'. The rhetoric of meritocracy has a strong flavour of favouritism that privileges the stance of inegalitarianism. ${ }^{5}$

It could hence be argued that meritocracy, as that which constitutes 'equal opportunities' does not entail equal outcomes. As Mr Heng Sweet Keat, then Minister for Education, points out, schools in Singapore are not meant to achieve 'identical outcomes' (Heng, 2014, n.p). In addition, he emphasises in an earlier speech:

We cannot guarantee equality of outcome, but we seek to provide equal opportunity for every student. We thus:

- Ensure that no child is deprived of educational opportunities because of their financial situation;

- Leverage on our school system to provide more support for families from poorer backgrounds;

- Invest in pre-school education targeted at children from families with poorer backgrounds; and

- Invest in levelling-up programs in primary schools that attempt to level up academically weaker students in both English and Mathematics, so as to improve their foundations for future learning.

(Heng, 2012, n.p.)

This claim seems to suggest that the aim of the education policies is not to elide the production of unequal outcomes, but rather, to rationalise them. Drawing on Lee Yock Suan's (quoted in Goh \& Gopinathan, 2008, p. 27) argument in the previous section, it may seem that the education system aims to deliberately (re)produce inequality in order to produce better economic outcomes for society. Further, in spite of this rhetoric and its defence of streaming 'to cater to different abilities of students for the good of all' (Teo, 2002b, n.p.), statistical trends have indicated that streaming has sustained systematically low academic achievement for a particular ethnic group. 


\section{Outcomes and critiques of the streaming policy: a moral political problem}

While official discourse seeks to defend streaming as central to achieving academic success, ethnic-based results released by the MOE from 1987 to 2011 indicate that Malay students in Singapore have been underperforming when compared to other ethnic groups in core subjects like English, Mathematics, and Science (MOE, 2012c, n.p.; 1997, n.p.) for 25 years. Consequently, they are over-represented in the Normal (Academic) and Normal (Technical) streams in secondary schools ${ }^{6}$ (Barr \& Skrbiš, 2008, p. 163; Rahim, 1998, pp. 121, 127; Sharpe \& Gopinathan, 2002, p. 158). Paradoxically, while the education system claims to implement meritocratic ideals, streaming appears to systematically reproduce Malay underachievement. As a large segment of the Malay population has continuously been channelled into the lower streams, this statistical representation not only serves as an indicator that an entire ethnic group is 'less academically inclined"7 than the rest of the ethnic groups, but more importantly, raises the possibility of a politically induced, systemic inequality as a point of investigation. That is, instead of accepting this unequal representation as an empirical given, this paper questions or brackets this presupposition, taking it as a provisional base for the possibility of systemic discrimination. Exposing the assumptions underpinning structural proposals and propositions in policy discourse can lend weight to this presumption.

Persistent underachievement would then serve as an apparent indicator of the systemic meritocratic inequality of the NES; that is, systematic inequality is inbuilt into the system, and gaps between the more and less 'academically inclined' would persist, despite claims of equal opportunities. Indeed, former prime minister Lee Kuan Yew 'asserted that the Malays would never close the gap in educational attainment with the Indians and Chinese because as they improve, the others also improve' (Lee, 2011 quoted in Lim, 2013, p. 4, emphasis included). If this argument is correct, then streaming can be seen as a sorting mechanism which serves to systemise and, more importantly, legitimise unequal access to knowledge according to whether a student is more or less 'academically inclined', and consequently, systematic inequality.

The common presumption about academic underachievement is that it resides primarily in those students with inadequate capacity to benefit from what the education system has to offer. Particularly, there has been a heavy reliance on the cultural deficit thesis ${ }^{8}$ to explain the educational marginality of the Malays (Rahim, 1998, p. 185). Exploring the historical, ethnic, and class-related factors to explain and address the Malay educational malaise is not the focus of this study. This would relegate and deflect attention from its central concern in examining how structural inequality is built-in to the system. There is a need to explore policies and their implications for structural reforms, as part of the problem. Rather than viewing learners as the locus of the problem, which entails deficit thinking 9 (Valencia, 2010), the analysis in this monograph points to the conditions under which unequal access to knowledge may occur. 


\section{Introduction}

In relation to systematic inequality, previous research reveals that the concept of an egalitarian meritocracy is unstable, as its constituent ideas, particular in relation to streaming within the education system, are potentially contradictory. Gopinathan (1996, p. 82) points out that by adopting streaming, Singapore abandoned the British practice of comprehensive schooling designed to equalise opportunities. Soon (1988, p. 19), in reviewing the public's reaction to streaming, advances the argument that pupils channelled to a lower course would have reduced access to higher education. As such, it is debatable whether attempts by the Ministry for equal opportunity (see previous section) characterised by levelling up academically weaker students (Heng, 2012, n.p.) have succeeded.

Cogently, Rahim (1998, pp. 120-124) argues that the PAP leadership's educational philosophy is driven by eugenics notions which influenced the belief that the innately 'talented' minority should be invested with a disproportionate amount of the state's public resources in order to lead and inspire the nation to succeed. Hence, various elite programmes for the educationally 'talented', as defined by policy, were institutionalised. The underlying assumption of this logic is that the more 'talented' students would generate economic growth for the nation in the long run. In his speech entitled 'Core Principles of Government', Deputy Prime Minister Lee Hsien Loong (1992, p. 22, quoted in Rahim 1998, p. 131) emphasises that, 'Because we have invested more in the more able, all Singaporeans have progressed faster'.

In relation to this, Tan $(2008$, pp. 7-10) points out that Singapore's concept of meritocracy that focuses on talent allocation, competition, and reward can obscure how an education system that emphasises efficiency systematically excludes particular groups of people based on race and class from the mainstream society, economy, and politics. He argues that a merit-based selection that focuses on the principle of non-discrimination may serve to both ignore and conceal the advantages and disadvantages of an unequal society. This practice perpetuates rather than levels inequality: those who are rewarded based on merit may already have a starting point of positional advantage. Further, compounded by policies such as the SAP ${ }^{10}$ (Special Assistance Plan) schools which favour the Chinese, Singapore's choice of meritocratic action strategy has continued to keep ethnic groups apart (Rahim, 1998, pp. 121, 127; Sharpe \& Gopinathan 2002, p. 158). Due to the privileging of differential access, these studies highlight that the pursuit of securing equality of opportunity is conceptually untenable and will be severely underestimated within streaming policy and practice, even if the official justification was constructed as catering to the ability of the learner (see Teo, 2002a, n.p.).

Whilst researchers (Rahim, 1998, pp. 117-118; Sharpe \& Gopinathan, 2002, p. 151; Soon, 1988, p. 19; Tan, 2008, p. 10) highlight the weaknesses of the education system and its role in sustaining academic or ethnic inequality, it is particularly instructive that such linkages between the system and the reproduction of inequality, particularly through education policy documents, remains unclear. That is, it is not clear how ability-based streaming is used as a mechanism through which inequality of educational opportunities is established, transmitted, and maintained. This is an especially important area of research given that educational and social 
consequences arising from underachievement can be severe, such as increasing income inequality (Sharpe \& Gopinathan, 2002, p. 158). Although inequality has been defended by the government as an inevitable consequence of globalisation, critics have pointed to the inadequacies of the education and training system (Sharpe \& Gopinathan, 2002, p. 158).

To add to the complexity of the issue, the field of Singapore's education policy analysis (see Rahim, 1998, pp. 123-124; Sharpe \& Gopinathan, 2002, pp. 155156) has been dominated by commentary and critique rather than empirical research. The lack of research using critical qualitative approaches that have the potential to challenge the 'ideological' premises of government policies is not surprising because of the political constraints on academic research in Singapore (Rahim, 1998, p. 8). The culture of self-censorship and lack of serious intellectual critique, particularly by researchers employed by Singapore's tertiary institutions, is likely to have been reinforced by the dismissal of the Deputy Secretary General of the Singapore Democratic Party, Chee Soon Juan, in 1992, from the Psychology and Social Work Department of the National University of Singapore on minor charges (Rahim, 1998, p. 8). Researchers tend to avoid investigating sensitive issues involving government policies such as the early streaming system (Gopinathan \& Gremli, 1988 as cited in Rahim, 1998, p. 8). To exacerbate matters, this self-control is also exercised by expatriate academics based on the experience of those "who have been detained for questioning and sued for defamation or have not had their contracts renewed for publishing articles critical of the PAP government' (Asiawatch, 1990, as cited in Rahim, 1998, p. 8). These substantive constraints against Singaporean scholars' overt critique of the state are real and, without a thorough examination, will likely encourage a disturbing trend of speculative research about the effects of policies.

Policies have direct material force in Singapore society. In The Public PolicyMaking Process in Singapore, Jon S. T. Quah (1984) points out that public policies are formulated by the cabinet, which is the 'supreme policy-making body of the government' (p. 113). The PAP government as the directive authority then ensures the successful implementation of policies to achieve the desired objectives by providing the 'necessary manpower, legislation, financial resources and equipment to the relevant implementing agencies' (p. 119). He highlights that the PAP government is 'not very tolerant of independent critics' who criticise government policies (p. 117). Furthermore, the inability of opposition parties to provide intelligent alternatives and to point out the flaws in policies has resulted in little or no public resistance (p. 119).

Within these factors, the rhetoric of meritocracy seems to be holding back the education system as it first allows a certain group to be systematically disadvantaged, and second, it does not allow incisive critique or the questioning of prevailing notions and prior assumptions within the system by which to improve it - because of the belief in the system as being fair on the basis that it is meritocratic and that every child has the same opportunity to succeed, thus resisting evidence of incoherence which leads to problems of inequality (see Bohm, 1994, p. 28). The notion of 'meritocracy' as conceptualised by official policy discourse as necessary needs to 


\section{Introduction}

be examined - that is, how has this concept been made necessary to the extent that 'it cannot be otherwise', which in effect is saying 'It has got to be this way. We have to keep it this way' (Bohm, 1994, p. 89). Employing CDA can uncover underlying assumptions in policy discourse that produce and sustain 'what subsequently counts as being self-evident, universal, necessary' (Foucault, 1991c, p. 87). The critical analysis employed here involves ideological deconstruction, which helps to discover underlying implicit assumptions of (absolute) necessity.

The central thrust here is thus concerned with how the ideological notion of 'meritocracy' is conceptualised through discursive processes in policy documents, rather than how it is theorised. The purpose here is not present what may be seen as a traditional literature review in the sense of summarising a series of mainstream perspectives on critical terms, but rather seeks to problematise the construction and use of this term in the first place. This is at the heart of this book's theoretical position. As such, to include the diverse theoretical groundings, which would constitute an ideal of what should be, or what has been stated of 'meritocracy' would be to undermine the conceptual integrity of the work. This analytical process which takes the problematisation of truth as a point of departure to examine what is Here and Now actually taking place within the policy data, rather than drawing on the historical, social, and political contexts to understand the object under investigation, provides a practical anchorage to the normative dimension of ideological critique. Here, the purpose is to examine how the idea of meritocracy works not as an abstraction, not as an idea, but in actuality. Further, a comparison with the situation in other countries in relation to meritocracy and education policy would not be of significant interest. It is not clear what is the basis or need for this comparison, or how differences could contribute to making up a coherent subject matter in trying to learn about Singapore's education system and its problems. To make sense of things against some background of previous or existing expectations or situations may hamper the observation of what is, what is Here and Now actually taking place within the policy data, although it may seem as though they were helping that observation by providing possibilities of what should be or what has been.

\section{Data-driven analysis}

Without evidence to prove and give clarity as to how ability-based streaming is a major mechanism through which inequality of educational opportunities is transmitted and maintained, assumptions by researchers exist about the perceived harmful effects of educational inequality under the rubric of meritocracy in policies. As such, the current position of streaming cannot be questioned or systematically distilled unless the language use in policy documents supporting this reality is fundamentally challenged (Liasidou, 2008, p. 485). In a fair and just society, it is the public's prerogative and responsibility to actively and continuously identify and question assumptions underlying the truths of policy proposals and propositions. Doing so can contribute to the progressive development of social policy for the future. 
The aim here is to make transparent the conditions under which streaming practices are producing inequality. As the legitimation of structural reforms is contingent on the assumptions that are operating, exposing the implicit assumptions embedded in policy proposals and propositions is a necessary, critical step to tackle structural inequality. The assumptions underlying policy proposals and propositions are not self-justifying and should not be taken as self-evident. Their legitimacy has to be demonstrated, failing which the structures that were built through these policies should be dismantled and reconstructed from below (Chomsky, 2013, p. 110). Given this possibility, this research focuses on how historically, education policies contribute to engineering consent for inequality within a meritocratic system. This is an area that has not been seriously examined in scholarly literature to date. Specifically, policy documents which are central to understanding how the system has been operationalised have not been explored and analysed in relation to this issue. This is clearly an area that needs investigation.

\section{Research trajectory}

Statistical trends and previous research raise the question of whether it is possible that a whole ethnic group is somehow less academically inclined. ${ }^{11}$ More importantly, it also raises the question of whether being more or 'less academically inclined' is inbuilt into the streaming system. In order to understand how the inconsistencies between educational meritocracy and inequity have been made manifest, this research aims to examine the actual policies where these initiatives were originally proposed, described, and ultimately implemented, using CDA. In tracing discursive shifts, which imply a 'complex, shifting field of relations' (Fraser, 1981, p. 283) between elements that legitimise social practices, policies can be used as important evidence in making explicit the implicit and opaque relationship between language and inequality so as to go beyond conjectural considerations (Taylor, 2004, p. 436). The observation of systematic formations that texts index and construct (Luke, 2002, p. 100) is then a vehicle through which to understand how the policies discursively construct the workings of the education system. Here CDA assumes policy language has social effects (Graham, 2001a, p. 765).

Given that these policy documents were commissioned by the Ministry of Education, the political nature of the policy and a principled and rigorous approach to issues of educational equity make it necessary to use a methodology that is capable of addressing political discourses. CDA is adopted as a powerful methodology to examine the discursive work of politically-based policy processes and formation. CDA provides a particular nuance to understand the subtle and intricate relationships of language to other social processes, and of how language works within power relations (Taylor, 2004, p. 436). In addition, CDA demands a rigorous systematic approach to provide a capacity for transparency through language analysis. More importantly, the methodology enables the examination of discursive processes as they unfold. 


\section{Introduction}

By tracing a historical sequence that has gone unbroken for 40 years - from the initiation of streaming in 1979 to 2019 - this study situates the construction of meritocratic inequality as a historically established fact. An analysis of the initial 1979 policy document and subsequent policies can provide a rich source of discursive evidence for the implicit relationship between language and social inequality (Taylor, 2004, p. 436). The use of the methodological approach of CDA to education policies can help to understand and uncover the conditions of this inequality (van Dijk, 1993, p. 369), by examining how policy texts manage the practice of systemic inequality discursively. The purpose is not one of finding mechanical patterns of causality, but to examine how a series of discursive practices make sense of or conceptualise systematic educational 'underachievement' within a meritocratic system. This would consequently provide a stronger ground for claims of discriminatory practices. Towards this end, this research is just as focused on the development of a more broadly applicable analytical CDA framework for the analysis of policies in general, especially those that are driven by neo-liberal economic agendas.

The positioning of subjects is central to legitimising the streaming policy. As previously discussed in the section 'Parallel media and official discourse on the 1979 MOE report' above, the three key elements that justify streaming in media and official discourse - to reduce educational wastage, to cater to different abilities of students for the good of all, and to minimise failures and damage to selfesteem - are discursively aligned with the 1979 report. Hence, this research examines how the identities of learners are discursively constructed in education policies. This investigation could potentially play a significant role in providing a preliminary understanding of how differential access to knowledge is legitimised.

Towards this end, this research develops a form of critical discourse analysis (CDA) to examine Singapore's Ministry of Education (MOE) policies on streaming in two stages. The first stage examines the original 1979 MOE report that proposed a streaming policy for Singapore. Foucault's archaeological method is used in combination with an amalgamation of CDA approaches to investigate how policy works to recognise, define, and classify learners through binary categorisations. This methodology critically examines the 'regime of truth' that makes possible capability-based identity constructs. This section of the study brings together Foucault's perspective on power-knowledge-truth, which provides insights into how learner identities are constructed within 'truth' claims, and CDA to describe, interpret, and explain the ways in which identities are constructed within policy discourse. By problematising truth - that is, making transparent the assumptions that underpin the truths in policy discourse, the analysis makes explicit the necessary conditions (of possibility) for the disclosure of what is pervasive and recurring, which in the case of this analysis, is the objectification of learners.

In order to grasp the changes in the conditions for the objectification of learners in successive policy texts, this approach is then developed in the subsequent genealogical-analytical stage of the research, which traces the historical and discursive construction of learner identities in policy texts from 1979 to 2019 and how they are constituted in various moral discourses. The genealogical method provided a 
basis from which to trace the regulatory forces and events that shape these discursive practices into a recursive network of power relations over time. This stage builds on the methodological and theoretical work of the first to formulate and employ a micro-meso-macro CDA framework to examine metaphors and the value of truth in policy texts. This framework draws upon a relationship between language analysis, the philosophical study of valuation, and political economy to analyse how changes associated with new modes of value determination serve to legitimise inequality within a frame of meritocracy. The concerns and questions of how social categories and practices are shaped by discourse that arises out of policy analysis found parallels in Foucault's and Nietzsche's theoretical and philosophical orientations. Together, this central mode of inquiry and philosophical orientations works in a critical analysis of policy discourse to understand how inequality can exist within a frame of meritocracy. This stage involves, simultaneously, the development of Foucault's work on the truth formulation of subjects by synthesising his philosophical perspective with the work of Nietzsche. Nietzsche's work is critical in mobilising an understanding of power, will, and truth by bringing the concept of valuation to centre stage in exposing the underlying assumptions that guide institutional practices for differentiated learners. The synthesis of these philosophical concepts with CDA is useful in critically analysing the formulation of truths that constitutes the focus of policymaking.

As revealed through this second stage of analysis, policy-oriented moralities are the principal means of fashioning men and women according to the pleasure of a creative and profound will, which has prevailed over time through multiform conditions of possibility that can change quite drastically (cf. Nietzsche, 1967a, p. 501 ). This will to power as 'being' is expounded in the form of values and valuation, ${ }^{12}$ revaluation and transvaluation (Nietzsche, 1967a). The production and gaining of knowledge breeds and is bred by these fragmented forms of valuation that relate value judgments to the ideology of economic growth. These valuations are hence an exercise of power that brings particular truths into being. To make concrete this philosophical dimension, this analytical stage synthesises the multiple layers of intersections between methods that have been developed by critical discourse analysts for analysing evaluations. In doing so, this study is concerned with the unfolding of the will to power, and simultaneously, the production of being ${ }^{13}$ of ideology of economic growth as that of the objective desire (cf. Heidegger, 2003 c, p. 141). The problematisation and critique of economic growth as the only way forward requires exposing and challenging the assumptions underlying this ideological logic. Within the context of this research, those assumptions allude to modes of e/valuation.

The analytical chapters reveal that whilst the initial discursive formations of policy texts were focused on catering to the constructed needs of learners with lower abilities, subsequent policy discourses revealed conflicted discourses and reworked policies towards the institutional practice of providing greater educational access for individuals with higher capabilities in relation to meeting the needs of changing political economies. This phenomenon of inequality of access can be explained by analysing how recursive metaphors of flexibility, diversity, 


\section{Introduction}

choice, and opportunity as time-travellers and as engines of neo-liberal discourse interact with one another. These metaphors operate as a fluid movement in and through the texts to provide the necessary foundation from which to hold unequal structural reforms as a justifiable, desirable form of ethical practice. The analysis concludes that objectification is a fundamental part of the valorisation process. Forms of objectification through identity categorisation increase the relative value of subjects through upskilling and modes of valuation within the perceived demands arising from the living movement and changing material conditions of surrealistic political economies.

\section{Significance of the research and its contribution to the field}

Even though previous research points to the weaknesses of streaming and its role in sustaining inequality, it is not clear how streaming is used as a mechanism through which inequality of educational opportunities is established, transmitted, and maintained. This problem is compounded by the political constraints on academic research in Singapore. Taking the reproduction of inequality as an observable fact, the assumption that policies play a critical role in reproducing inequality is central to this research. Towards this end, CDA is employed to analyse policy texts in order to make explicit and provide critical evidence as to how inequality is inbuilt into the education system. To begin the analysis with 'how' is to suggest that systemic inequality (re)produced through policies as such does not exist until it has been made explicit under or in what conditions this is so (cf. Foucault, 1982a, pp. 778, 785-786). 'How' in this sense, as Foucault argues, is the discursive means in which inequality is re(produced) in policy discourse (cf. Foucault, 1982a, p. 786). The analysis in this monograph illustrates how forms of valuations perpetuated by and through policy discourse are the motivational locus of meaning making insofar as they strongly inform the moral force driving the overarching ideological narrative of economic growth. To build this larger 'content' using typical sociological sources or socio-historical contexts would be incompatible with the carefully developed theoretical-methodological approach. The monograph's analysis and focus are explicitly directed at the internal reasoning within the texts and where the evolving state of other aspects of linguistic representations, along with any other institutional or political or public sphere, is irrelevant to the text unless it is brought to bear within the texts in some discursive capacity.

The contribution this study makes to the field is twofold. First, the analysis of Singapore's education policies makes explicit how streaming is a major mechanism through which unequal opportunities are transferred and sustained. Second, it makes a contribution to policy analysis more broadly, contributing to a new political front in education, one that puts philosophy to work - in terms of the integration and application of suitable, multiple CDA approaches in analysing policies - in those paradigms in which education policies are conceptualised, theorised, and researched. That is, it adds to scholarship on not just educational policy in general, but more specifically to scholarship around issues of equality and 
the construction of learner identities. In constructing a working methodology for policy analysis, it aims to strengthen discourse analytical work by bringing the tools and perspectives of the philosophical study of valuation to bear on concrete problems that arise in addressing issues of education policy and practice.

\section{Organisation of the monograph}

This section provides an outline of the book, describing the ways in which each chapter sets out the research. Chapter 2, 'Creating the Conditions for Division and Structural Inequality: The Human Being as a Historical Construct', provides a preliminary, archaeological investigation into how policy works to recognise, define, and classify learners through binary categorisations. The purpose of the analysis is to examine how learners are represented in the original $1979 \mathrm{MOE}$ report that introduced streaming. As an initial conceptual framework for analysing that report, this chapter primarily discusses Foucault's interweaving concepts of power-knowledge-truth, which explore the relations between subject and truth. Foucault uses the term 'power/knowledge' to signify that power is constituted through accepted forms of knowledge and 'truth'.

Through this, the chapter discusses Foucault's archaeological method and its suitability for a philosophically grounded, interdisciplinary piece of linguistic research in examining the objectification of subject. By detailing the source of the various approaches to CDA, the chapter presents a 'multidisciplinary' approach to discourse analysis. The analysis of the 1979 MOE report makes explicit the conditions necessary for identifying particular types of learners and how this is related to structural reforms. Three conditions emerge from this preliminary analysis: 'capabilities as social change', 'inequality as justice', and 'ethics: or philosophy of desirability'. They provide a basis for the genealogical research trajectory of the rest of the analysis of this research.

Out of the three, the third condition, the employment of 'ethics: or philosophy of desirability' (Nietzsche, 1967a, p. 181) in policy discourse is central to the analysis. An examination of ethical practices in policy discourses repeatedly reflects first the utilisation of specific metaphors. Second, the analysis demonstrates that a value system that is produced and reproduced in the theme of ethics is profoundly enmeshed in the impetus for social change and the conceptualisation of justice. Hence, an investigation of the theme of ethics would mean an investigation of the other two themes.

Chapter 3, 'Using Genealogy and Ethics to Investigate the Conditioning of Human Beings into Moral Subjects Who Desire More', unpacks the term 'genealogy' and the relationship that it bears to archaeology discussed in Chapter 2. The aim of the chapter is to examine how historical qualitative textual analysis might be located within the philosophical interstices of archaeology, genealogy, and CDA (cf. Anais, 2013, p. 125). This includes a treatise on a genealogy of ethics which entails the study of the modes according to which the subject is inserted as an object in the games of truth - alluding to the Truth of economic growth. For the purposes of this research, modes are conceptualised as (historical) conditions 


\section{Introduction}

of possibility for differential learner treatment to exist in the analysis of economic growth and neo-liberalism for labour appropriation (Foucault, 1982a, p. 777). The chapter further outlines a synthesis of relevant CDA approaches, designed to operationalise Foucault's and Nietzsche's philosophical orientations on schemas of valuation in order to understand how human beings have been conditioned as moral subjects in relation to value-forming labour appropriation who desire economic growth.

Chapter 4, 'Micro-Meso-Macro Movements: A Multi-Level Critical Discourse Analysis Framework to Examine the Value of Truth', aims to model how CDA and Foucault's philosophical concepts, combined with Nietzsche's concept of truth, can be usefully synthesised to analyse schemas of valuation in education policies that have identifiable material force in structural inequality. The aim is to convert their philosophical concepts into an analytical framework capable of addressing empirical data. That is, it explores how evaluative semantic categories can be linked to sociological theories in order to bring out their relevance for the purpose of CDA. In doing so, the philosophical-analytical framework aims to make analytically observable how changes associated with new modes of value determination serve to legitimise inequality. Their philosophical perspectives are determined by the poles of valuation and truth. By drawing on these philosophical themes, arguments, and ideas, the analysis lays bare relations of power through valuations. The research argues that the abstract convergence of truth and valuation has quite specific and concrete structural implications in relation to differed structural access to knowledge.

In examining how specific values and outcomes are made desirable, Chapters 5 to 7 adopt a genealogical analytic approach that emphasises the importance of recursive discourses of the original 1979 MOE report and subsequent 1979-2019 policies. In doing so, it reveals the pervasiveness (Foucault, 1972, p. 221) of policy metaphors of flexibility, diversity, choice, and opportunity. Three themes emerged from the analysis of the preliminary theme of 'Ethics: or Philosophy of Desirability'. The first theme, 'Metaphorical Realism', illustrates how metaphors do ideologising work to varying degrees, in the service of contributing to and sustaining systemic educational inequality through micro-macro valuations.

Chapter 5, 'Theme 1: Metaphorical Realism', the first of the three themes, proposes and employs the notion of 'metaphorical realism'. The notion entails a focus on how the metaphors of flexibility, choice, diversity, and opportunity appear to contribute and sustain systemic educational inequality through both micro and macro valuations. As such, they serve as a critical principle of institutional differentiation. In its philosophical dimension, 'metaphorical realism' proposes that these metaphors are treated as apparatuses of power, where power includes forms of valuation that serve to turn idealised and politically induced images of the system into multiple organisations of truths that support inequality. These truths shape and retain competing economic imaginaries; that is, they construct illusions of desirable realities. This chapter presents the overarching, interacting, and intersecting constructions of macro-neo-liberal values of competitiveness, de/regulation, and market economies. It sets up the frame that 
these macro-neo-liberal values are both conditional upon and being conditioned by micro valuations of what is interpreted as important or/and necessary to generate desirable outcomes. ${ }^{14}$ Both macro and micro valuations are analysed in the next two themes.

Chapter 6, 'Theme 2: De/regulation', builds on the analysis in Chapter 5 to examine how the metaphor of flexibility performs ideologising work that obscures the agent or agency involved in generating desirable outcomes. Specifically, it examines how the metaphor of flexibility appears to do ideologising work to obscure the agent or agency involved in generating desirable outcomes. The chapter explores how the lack of agency can serve to obfuscate state responsibility with respect to policy trajectories. More importantly, this chapter examines how the lack of (state) agency in discourse underplays the potential of active agents. It proposes how devolution to educators and transformation to a flexible system in no way entails relinquishing state control by illustrating the centripetal movement of power in educational governance. The analysis illustrates how policies are presumably oriented to a general depoliticisation of responsibilities in relation to decentralisation.

Chapter 7, 'Theme 3: Political Economies of Surrealism', examines how metaphors appear to be ideologising work to bring together realities that appear to have limited logical relationship or rational link, to produce conditions of emerging political economies that permit new knowledge and new truths (cf. Adonis, 2005, p. 41). Specifically, this chapter calls the 'real' notion of reality into question through the notion of 'surrealism'. This chapter ties previous analyses into a wider reflection on how metaphors sustain the ideology of economic growth as the only way forward. Throughout the three movements, the texts reveal a set of correlations through the play of positive significations that it ascribes to the idealised images. These correlations exist between the metaphors of flexibility, diversity, choice, and opportunity, social-economic life, and an indivisible whole system of differential valuations. Further, these metaphors are used to advance capitalistcorporatist imperatives (cf. Graham \& Luke, 2011, p. 106; cf. Foucault, 1997, pp. 90-91). By alluding to macro-neo-liberal values of competitiveness, de/regulation, and market economies, these three movements argue that inequality is desirable. The organisation of values is thus at the same time a 'mechanism of selection and exclusion' (Foucault, 2001, p. 173).

Chapter 8 is titled 'Inequality as Meritocracy'. The discussion in this chapter relates the material presented in previous chapters to the theoretical and operational objectives of the study. That is, it outlines the specific aims of the research and its theoretical and methodological contributions to the field of critical discourse analysis scholarship. The research draws on a theoretical framing from Foucault augmented by Nietzsche's views on valuation to develop a multi-level CDA framework for policy analysis and to make analytically observable how changes associated with new modes of value determination serve to legitimise educational inequality within a meritocratic education system. Overall, the research argues that metaphors are central to recontextualising, disseminating, and legitimating dominant political imaginaries that construct and sustain structural 


\section{Introduction}

inequality for economic growth. It then presents a critique of the philosophicalanalytical concerns of the study. More importantly, in demonstrating how education policies are unfounded and unsupported by the idea of meritocracy, the chapter proposes an opportunity for the emergence of a 'Singapore model' to lead education policies for advanced economies.

\section{Summary}

Driven by economic imperatives and efficiency, streaming was introduced as a policy in 1979 and an explicit form of structuration became widely practised in schools. While official discourse seeks to defend streaming as central to achieving success and reducing attrition rates, statistics released by the MOE indicate that Malays have been underperforming since 1987. In order to understand how the inconsistencies between educational meritocracy and inequity have been made manifest, this research aims to analyse education policies from 1979 to 2019. Policy texts can be used as important evidence in making explicit the opaque relationship between language and inequality. This process is necessary so as to go beyond speculation and demonstrate how policy texts work in order to provide empirical support for previous claims of discriminatory practices through which structural inequality of educational opportunities is established, transmitted, and maintained. In using CDA to expose underlying assumptions in policy discourse, it is possible to make visible how policy discourses justify, legitimise, and sustain unequal opportunities for knowledge access and differentiated treatments within a meritocratic system.

The next chapter moves on to an analysis of the 1979 MOE report. This preliminary analysis will provide an initial understanding of how inequality of access is inbuilt and sustained within the system through dichotomous conceptions of learner identities that are a product of power-knowledge-truth relationships inherent in policy discourses (Foucault, 1969, 1972, 1979, 1981 as cited in Rogers et al., 2005, p. 370). More importantly, this initial analysis is a necessary, preliminary step in providing an analytical-genealogical trajectory for further investigation.

\section{Notes}

1 'Streaming is underpinned by the fundamental belief that students had varying learning ability, and would therefore be better off being grouped together to learn at their appropriate pace. Put simply, streaming allows each child to better fulfil his inherent potential' (Ng, 2008a, n.p.).

2 Where CDA is concerned with analysing language 'as one element of the social process dialectically interconnected with others', in order to demonstrate the ways 'socio-economic systems are built upon the domination, exploitation, and dehumanization of people by people, and to show how contradictions within these systems constitute a potential for transforming them in progressive and emancipatory directions' (Fairclough \& Graham, 2002, p. 5).

3 Students in the Express course at the end of Secondary 4 typically offer six to eight subjects at the Singapore-Cambridge General Certificate of Education (Ordinary Level) examination. Those with exceptional academic ability may offer a ninth subject (MOE, 2012b, p. 6). 
4 A pre-university course leading to the Singapore-Cambridge General Certificate of Education (Advanced Level) Examination prepares students for further education by equipping them with the essential skills and knowledge required for tertiary education (MOE, 2012b, p. 8).

5 The characteristics of how the term 'egalitarianism' is mobilised and made sense of in the context of Singapore's education policy will be explicated in the section 'Egalitarian-excellence educational philosophies' of Chapter 2.

6 Generally, at the end of four years, students who are placed in the Express stream sit for the Singapore-Cambridge General Certificate of Education Ordinary Level (GCE O-Level) examination. Students who are placed in the Normal (Academic) stream sit for the Singapore-Cambridge General Certificate of Education Normal (Academic) Level (GCE N(A)Level) examination, then one additional year to prepare for the GCE O-Level examination. Students who are placed in the Normal (Technical) stream sit for the Singapore-Cambridge General Certificate of Education Normal (Technical) Level (GCE N(T)-Level) examination to gain entry into the Institute of Technical Education (ITE), which offers a technical-vocational education (Normal course curriculum, n.d., n.p.).

7 This term was used by the Minister for Education, Ong Ye Kung, at the Schools Work Plan Seminar on 28 September 2018 in relation to the current school curriculum which 'caters to students of different learning paces and learning needs'.

8 The cultural deficit thesis, which suggests that academic achievement is culturally based and so the problem lies primarily within the Malay community (Rahim, 1998, p. 186), can be linked to Bernstein's and Bourdieu's competence models of language and human development within class-based societies (see Collins, 2000). Their research programmes, which focus on social and educational reproduction, draw on mechanisms of socialisation and subjectivity (Collins, 2000, pp. 65-66).

9 Valencia argues that deficit thinking operates on an unsubstantiated assumption that inherent abnormalities such as limited intellectual ability, low motivation, and linguistic shortcomings are the source of academic failure among low socioeconomic-class students. Rather than relying on this 'blaming the victim' thesis to explain educational malaise, Valencia observes that systemic factors, such as inequities in basic school resources, have a strong relationship to the academic failure of low-SES students (Garcia-Perez, 2012, pp. 278-279).

10 The SAP scheme was introduced in 1979 to preserve the best traditions and ethos of the old Chinese medium schools, and to nurture a core group of students who are proficient in both English and Chinese. Currently, there are 11 SAP secondary schools and 15 SAP primary schools (MOE, 2008b, n.p.).

11 This term was used by the Minister for Education, Ong Ye Kung, at the Schools Work Plan Seminar on 28 September 2018.

12 Valuation here as 'I believe that this and that is so' as the essence of 'truth' (Nietzsche, $1967 \mathrm{a}$, p. 275 , italics included). The term here denotes the desirability of certain acts.

13 The disclosure of this 'being' is understood in 'terms of the conditions of their possibility' (Heidegger, 2003c, p. 238). Through the analysis in this research, 'being' is conceptualised as a fluid, continual flux of discursive formations to bring the ideology of economic growth into immanent existence, and the constant anticipatory state of potential becoming of surrealistic economies.

14 Desirable outcomes are conceptualised in this study as those which increase economic growth through appropriation of labour for irrealis industrial economies. See the section 'The desiring-desirable subject, hyperrealist structures, and schemas of valuation as elements of ethical relations within the "games of truth" of Chapter 3. 


\section{Notes}

\section{Chapter 1}

1 'Streaming is underpinned by the fundamental belief that students had varying learning ability, and would therefore be better off being grouped together to learn at their appropriate pace. Put simply, streaming allows each child to better fulfil his inherent potential' (Ng, 2008a, n.p.).

2 Where CDA is concerned with analysing language 'as one element of the social process dialectically interconnected with others', in order to demonstrate the ways 'socio-economic systems are built upon the domination, exploitation, and dehumanization of people by people, and to show how contradictions within these systems constitute a potential for transforming them in progressive and emancipatory directions' (Fairclough \& Graham, 2002, p. 5).

3 Students in the Express course at the end of Secondary 4 typically offer six to eight subjects at the Singapore-Cambridge General Certificate of Education (Ordinary Level) examination. Those with exceptional academic ability may offer a ninth subject (MOE, 2012b, p. 6).

4 A pre-university course leading to the Singapore-Cambridge General Certificate of Education (Advanced Level) Examination prepares students for further education by equipping them with the essential skills and knowledge required for tertiary education (MOE, 2012b, p. 8).

5 The characteristics of how the term 'egalitarianism' is mobilised and made sense of in the context of Singapore's education policy will be explicated in the section 'Egalitarian-excellence educational philosophies' of Chapter 2.

6 Generally, at the end of four years, students who are placed in the Express stream sit for the Singapore-Cambridge General Certificate of Education Ordinary Level (GCE O-Level) examination. Students who are placed in the Normal (Academic) stream sit for the Singapore-Cambridge General Certificate of Education Normal (Academic) Level (GCE N(A)Level) examination, then one additional year to prepare for the GCE O-Level examination. Students who are placed in the Normal (Technical) stream sit for the Singapore-Cambridge General Certificate of Education Normal (Technical) Level (GCE N(T)-Level) examination to gain entry into the Institute of Technical Education (ITE), which offers a technical-vocational education (Normal course curriculum, n.d., n.p.).

7 This term was used by the Minister for Education, Ong Ye Kung, at the Schools Work Plan Seminar on 28 September 2018 in relation to the current school curriculum which 'caters to students of different learning paces and learning needs'.

8 The cultural deficit thesis, which suggests that academic achievement is culturally based and so the problem lies primarily within the Malay community (Rahim, 1998, p. 186), can be linked to Bernstein's and Bourdieu's competence models of language and human development within class-based societies (see Collins, 2000). Their research 
programmes, which focus on social and educational reproduction, draw on mechanisms of socialisation and subjectivity (Collins, 2000, pp. 65-66).

9 Valencia argues that deficit thinking operates on an unsubstantiated assumption that inherent abnormalities such as limited intellectual ability, low motivation, and linguistic shortcomings are the source of academic failure among low socioeconomic-class students. Rather than relying on this 'blaming the victim' thesis to explain educational malaise, Valencia observes that systemic factors, such as inequities in basic school resources, have a strong relationship to the academic failure of low-SES students (Garcia-Perez, 2012, pp. 278-279).

10 The SAP scheme was introduced in 1979 to preserve the best traditions and ethos of the old Chinese medium schools, and to nurture a core group of students who are proficient in both English and Chinese. Currently, there are 11 SAP secondary schools and 15 SAP primary schools (MOE, 2008b, n.p.).

11 This term was used by the Minister for Education, Ong Ye Kung, at the Schools Work Plan Seminar on 28 September 2018.

12 Valuation here as 'I believe that this and that is so' as the essence of 'truth' (Nietzsche, $1967 \mathrm{a}$, p. 275 , italics included). The term here denotes the desirability of certain acts.

13 The disclosure of this 'being' is understood in 'terms of the conditions of their possibility' (Heidegger, 2003c, p. 238). Through the analysis in this research, 'being' is conceptualised as a fluid, continual flux of discursive formations to bring the ideology of economic growth into immanent existence, and the constant anticipatory state of potential becoming of surrealistic economies.

14 Desirable outcomes are conceptualised in this study as those which increase economic growth through appropriation of labour for irrealis industrial economies. See the section 'The desiring-desirable subject, hyperrealist structures, and schemas of valuation as elements of ethical relations within the "games of truth" of Chapter 3.

\section{Chapter 2}

1 The concepts of genealogy and ethics are elucidated in Chapter 3 .

2 The philosophical perspectives drawn on for this research are elucidated in Chapters 2, 3, and 4 .

3 An alternative reading could include a kind of paternalism here; that is, 'we' should 'care' for these children and not let them be unduly harmed by a competitive education system.

4 It is beyond the scope of this study, but it may be useful to look at how pupils are valued based on categories, that is, 'bright' students are more desirable for the nation at large. The notion of 'desirability' is then subsumed under the notion of normality. However, as explicated in Chapters 5, 6, and 7, this research focuses on desirability in terms of desirable outcomes within the future-oriented logic of policy discourse.

5 It might be argued that, rather than imbuing them with esteem issues, a paternalistic point of view implicit in this text seeks to protect them from acquiring esteem issues, that is, to prevent them from becoming particular kinds of subjects that would be inevitable in a competitive system. It is possible for the discourse to be read as both - as offering a kind of paternal care while at the same time categorising them as having deficits.

6 The PSLE, or Primary School Leaving Examination, is conducted in Singapore annually. It is a national examination which pupils sit at the end of their final year of primary school education (General information, 2015, n.p.)

7 Recommendations for a primary school subject-based banding policy and the Teach Less Learn More (TLLM) policy, and the rationale for both, were communicated by former Minister of Education Tharman Shanmugaratnam at the 2006 and 2005 Work Plan Seminars respectively rather than reports by committees. 


\section{Chapter 3}

1 These metaphors appear pervasively in Chapters 5 to 7 from the analysis of the third theme of 'ethics: or philosophy of desirability' that emerged from Chapter 2.

2 While realis spaces refer to states that exist in the here-and-now, irrealis spaces portray future and imagined states (Graham, 2001a, p. 767).

3 The concept of surrealism is further elucidated in Chapter 7.

4 Policy speeches embed coding senses of 'we' - inclusive we, exclusive we, and ambivalent we - that constitutes inclusion and shared responsibility. This makes the genre particularly hortatory (see Mulderrig 2011b, pp. 568-569). Through this process, speeches engage the people to behave in certain desired ways (see section 'Micro-meso movement: Contractual-ethical discourse for talent investment' of Chapter 5).

5 See Foucault (1981c): Part One, 'Dreaming of One's Pleasure' in The Care of the Self (The History of Sexuality Volume 3).

6 This term is explicated in the section, 'The relationship between the objectification of learners, valuation, and political economies' of Chapter 3.

7 Neo-liberalism as a system of principles of valuation and evaluation is explicated in the section, 'Neo-liberalism as a system of principles of valuation and evaluation' of Chapter 4.

8 The 'care of the self' can be conceived of as a specific governmental apparatus used as part of 'governmental rationality' or 'governmentality' to manage populations and the state's impertinent intervention into detailed aspects of our everyday lives (Foucault, 1991c, pp. 102-103).

9 Chapter 4 develops a multi-level, philosophical-analytical framework that incorporates the philosophical study of valuation and political economy with CDA approaches.

10 This principle is explicated in the section 'Micro-meso-macro' of Chapter 4.

11 Fairclough 1992; 1995; 2001; 2000; 2003; 2005; 2006a; 2006b; 2009, 2010.

12 Two concepts of 'value' are at work in Graham's analysis. They condition, and are being conditioned by the other. The first concept of value is perceived as important, necessary, and desirable (Graham, 2002, p. 245). The second concept of value pertains to the Marxist critique of production, the creation of value via the labour process (Marx, 1973, as cited in Graham \& Luke, 2011, p. 106).

The concept of value within the context of this research, while not drawing on Marx, also explores how forms of valuations relate to processes of labour appropriation. The concept of labour appropriation draws on Foucault's (1982a, pp. 777-778) work on the 'modes of objectification which transform human beings into subjects', and how the 'human subject is placed in relations of production and signification'. The concept of value is here is linked to the production of truth (Foucault, 1982a, p. 783).

\section{Chapter 4}

1 'Transvaluation of values' here is not to be understood as Nietzsche's concept of bringing about 'a triumph of opposite values' (Nietzsche, 1924, p. 178) but the trans-substantial motion in the form of temporal metaphorical transfers (Graham, 200la, p. 770; 2005, p. 123; Lemke, 1998, p. 45). In relation to the ongoing conceptualisation of the methodological framework within this study, it is proposed that the entirety of the value system flows from the transfers of micro-macro valuations through the propagation of metaphors.

2 'The will is not a single entity but more like a constantly shifting federation or alliance of drives' (Nietzsche, 1967a, p. 381).

3 There is considerable sociological literature conceptualising and theorising valuation and evaluation within the workings of the market that is beyond the scope of this study (see, for example, Carruthers \& Stinchcombe 1999; Zelizer 1979; 2011) - the focus here is on how modes of value determination are situated and mobilised within the discursive processes in the documents, rather than a treatise on these theories. However, it is relevant to note that Lamont $(2012$, p. 205) considers valuation practices as 'giving worth 
or value' and evaluative practices as 'assessing how an entity attains a certain type of worth'. Evaluation is therefore conceived as an act of valuing - though it is more than this as it includes a possible action of arguing for a valuation. Thus, in policy discourse, it is possible for both valuation and evaluation to be interchangeable and interdependent as each conditions and is conditioned by the other.

4 How budgets are made and how resources are allocated (in Singapore) are decided on the basis of policies (Quah, 1984, p. 119).

5 To elaborate, this research draws on Bohm's account of how the general structure of matter may be understood in terms of enfoldment and unfoldment to the implicate $\operatorname{order}$ (from a Latin root meaning 'to enfold' or 'to fold inward'), the central underlying theme of which is the notion of 'unbroken wholeness of the totality of existence as an undivided flowing movement without borders' (1980, pp. 172, 177-180).

6 '(meso)' here emphasises its intermediary role as explicated in the 'Micro-meso-macro' section above.

7 There are three themes and each is analysed at three levels.

\section{Chapter 5}

1 Junior College.

2 Vocational and Industrial Training Board.

3 National Technical Certificate Grade 2.

\section{Chapter 6}

1 Although examining the construction of gendered subject positionings and terminology in policy discourse is not the focus of this chapter, attention must be drawn to the use of the pronoun 'his'. It is not gender-neutral and possibly inbuilds gender inequality and male dominance (cf. van Dijk, 1993, p. 255) by projecting that all heads of schools will be male and cannot be female.

\section{Chapter 7}

1 'One must vivre, pour vivre pour autrui: Live to live for others' (Nietzsche, 1967a, p. 415).

2 Although this argument is a sidebar to this chapter, Smith's (1759 [2010], p. 99) Theory of Moral Sentiments provides the ethical and philosophical underpinnings for political-economic morality and the sense of duty: 'All the rich do is to select from the heap the most precious and agreeable portions. They consume little more than the poor, and in spite of their natural selfishness and greed, and despite the fact that they are guided by their own convenience, and all they want to get from the labourers of their thousands of employees is the gratification of their own empty and insatiable desires, they do share with the poor the produce of all their improvements [meaning: their well-cultivated land, their up-to-date ploughs, their state of the art milking sheds, etc.]. They are led by an invisible hand to share out life's necessities in just about the same way that they would have been shared out if the earth been divided into equal portions among all its inhabitants. And so without intending it, without knowing it, they advance the interests of the society as a whole and provide means for the survival of the species.'

3 Thinking Schools, Learning Nation.

4 Primary School Leaving Examination.

5 It also evokes the traditional capitalist and classical economics assumption of the infinitely flexible perfectly 'supply' of labour (labour market flexibility) able to move effortlessly to adjust to changes in demand in particular industries, and thereby relegating the possibility and problem of unemployment.

6 Singapore Institute of Technology. 


\section{Chapter 8}

1 The surrealis state is the juxtaposition of both realis and irrealis spaces (cf. Graham, 2000 , p. 761).

2 This term was used by Minister for Education, Ong Ye Kung at the Schools Work Plan Seminar on 28 September 2018 in relation to the current school curriculum which 'caters to students of different learning paces and learning needs' (Ong, 2018, n.p.).

3 Singapore tops the world PISA (the OECD's Programme for International Student Assessment) scores in mathematics, science, reading, and collaborative problem solving, and in TIMSS (Trends in International Mathematics and Science Study). Singapore is number two in the world in PIRLS (Progress in International Reading Literacy Study), and has one of the smallest proportions of low performers in PISA, TIMSS, and PIRLS (Rajah, 2018, n.p.). 


\section{References}

Adonis. (2005). Sufism and surrealism. London: Saqi.

Alvesson, M. \& Karreman, D. (2000). Varieties of discourse: On the study of organizations through discourse analysis. Human Relations, 53(9), 1125-1149.

Anais, S. (2013). Genealogy and critical discourse analysis in conversation: Texts, discourse, critique. Critical Discourse Studies, 10(2), 123-135.

Anderson, N.A. (2003). Discursive analytical strategies: Understanding Foucault, Koselleck, Laclau, Lubmann. Bristol: The Policy Press.

Archer, L. (2007). Diversity, equality and higher education: A critical reflection on the ab/ uses of equity discourse within widening participation. Teaching in Higher Education, 12 (5-6), 635-653.

Asher, N.Benamara, F. \& Mathieu, Y.Y. (2009). Appraisal of opinion expressions in discourse. Lingvisticae Investigationes, 32(2), 279-292.

Astiz, M.F., Wiseman, A.W. \& Baker, D.P. (2002). Slouching towards decentralization: Consequences of globalization for curricular control in national education systems. Comparative Education Review, 46(1), 66-88.

Ball, S. (1997). Policy sociology and critical social research: A personal review of recent education policy and policy research. British Educational Research Journal, 23(3), $257-274$.

Barr, M. \& Skrbiš, Z. (2008). Constructing Singapore: Elitism, ethnicity and the nationbuilding project. Copenhagen: NIAS.

Betts, R.H. (1975). Multiracialism, meritocracy and the Malays of Singapore (doctoral dissertation). Massachusetts Institute of Technology, U.S.A. Retrieved from http://sea rch.proquest.com.ezproxy.library.uq.edu.au/docview/302759626

Bevir, M. (1999). Foucault and critique: Deploying agency against autonomy. Political Theory, 27(1), 65-84.

Bohm, D. (1980). Wholeness and the implicate order (2nd edn). London: Routledge \& Kegan Paul.

Bohm, D. (1987). Unfolding meaning: A weekend of dialogue. London: Routledge.

Bohm, D. (1994). Thought as a system. London: Routledge. Retrieved fromhttps://s3.ama zonaws.com/arena-attachments/2223192/ee192aafe12e54lbe6b3262b5f1939al.pdf

Bohm, D. (2004a). On creativity. Routledge Classics: London \& New York.

Bohm, D. (2004b). On dialogue. Routledge Classics: London \& New York.

Bohm, D. (2005). The essential David Bohm. L. Nichol (Ed.). Taylor \& Francis e-Library. Retrieved from http://cspeech.ucd.ie/Fred/docs/Bohm_2005_.pdf

Bohm, D. (2006). Unfolding meaning: A weekend of dialogue. London: Routledge. 
Bohm, D. \& Peat, F.D. (2010). Science, order, and creativity. Taylor \& Francis e-Library. Retrieved from file: ///C:/Users/nadir/Downloads/epdf.pub_complete-seriesbundle-rc-science-order-and-creati.pdf

Brown, B. \& Cousins, M. (1986). The linguistic fault: The case of Foucault's archaeology. In M. Gane (Ed.), Towards a critique of Foucault (pp. 33-60). London: Routledge.

Bucholtz, M. (2001). Reflexivity and critique in discourse analysis. Critique of Anthropology, 21(2), 165-183.

Burchell, G. (2006). Liberal government and techniques of the self. Economy and Society, 22(3), 267-282.

Carruthers, B.G. \& Stinchcombe, A.L. (1999). The social structure of liquidity: Flexibility markets and states. Theory and Society, 28(3), 353-382.

Chan, R. (2014, ll February). Income + wealth inequality = More trouble for society. The Straits Times. Retrieved from www.straitstimes.com/singapore/income-wealth-inequa lity-more-trouble-for-society

Channel NewsAsia. (2016, 27 January). MPs call for rethink of streaming, specialist schools, emphasis on exams. Retrieved from: https://www.channelnewsasia.com/news/ singapore/mps-call-for-rethink-of-streaming-specialist-schools-emphasis-on-8209648

Chia, Y.T. (2011). The loss of the 'World-Soul'? Education, culture and the making of the Singapore developmental state, 1955-2004 (doctoral dissertation). University of Toronto, Canada. Retrieved from http://search.proquest.com.ezproxy.library.uq.edu.au/ docview/919571969

Chilton, P. (1996). Security metaphors: Cold war discourse from containment to common house. New York: Peter Lang.

Chomsky, N. (2013). On anarchism. New York: New Press.

Collins, J. (2000). Bernstein, Bourdieu and the new literacy studies. Linguistics and Education, $11(1), 65-78$.

Davidson, A.I. (1986). Archaeology, genealogy, ethics. In D.C. Hoy (Ed.), Foucault: A critical reader (pp. 221-233). Oxford: Blackwell.

Davidson, A.I. (2005). Ethics as ascetics: Foucault, the history of ethics, and ancient thought. In G. Gutting (Ed.), The Cambridge companion to Foucault. 2nd edn (pp. 115-140). Cambridge: Cambridge University Press.

Davie, S. (2019, 6 March). Subject-based banding to replace streaming in schools. The Straits Times. Retrieved from https://www.straitstimes.com/singapore/education/sub ject-based-banding-to-replace-streaming-in-schools

Dopfer, K., Foster, J. \& Potts, J. (2004). Micro-meso-macro. Journal of Evolutionary Economics, 14(3), 263-279.

Dr Goh pinpoints the three real causes of trouble in the system. (1979, 28 March). The Straits Times. Retrieved from http://eresources.nlb.gov.sg/newspapers/Digitised/Arti cle/straitstimes19790328-1.2.43.aspx

Dreyfus, H.L. \& Rabinow, P. (1983). Michel Foucault: Beyond structuralism and hermeneutics. Second edition with an afterword by and an interview with Michel Foucault. Chicago: University of Chicago Press.

Edelman, M. (1995). From art to politics: How artistic creations shape political conceptions. Chicago: University of Chicago Press.

Edwards, R., Nicoll, K. \& Tait, A. (1999). Migrating metaphors: The globalization of flexibility in policy. Education Policy, 14(6), 619-630.

Fairclough, I. \& Fairclough, N. (2012). Political discourse analysis: A method for advanced students. London: Routledge.

Fairclough, N. (1992). Discourse and social change. Cambridge: Polity Press. 
Fairclough, N. (1993). Critical discourse analysis and the marketization of public discourse: The universities. Discourse and Society, 4(2), 133-168.

Fairclough, N. (1995). Critical discourse analysis: Papers in the critical study of language. Harlow: Longman.

Fairclough, N. (1999). Global capitalism and critical awareness of language. Language Awareness, 8(2), 71-83.

Fairclough, N. (2000a). New Labour, new language?London: Routledge.

Fairclough, N. (2000b). Language and neo-liberalism. Discourse and Society, 11(2), 147-148.

Fairclough, N. (2001). Language and power (2nd edn). Harlow: Longman.

Fairclough, N. (2003). Analysing discourse: Textual analysis for social research. London: Routledge.

Fairclough, N. (2005). Discourse in processes of social change: 'Transition' in Central and Eastern Europe. British and American Studies, 11, 9-34.

Fairclough, N. (2006a). Metapragmatics, hidden assumptions, and moral economy. Retrieved from www.academia.edu/3778294/Metapragmatics_hidden_assumptions_and_moral_ economy_2006_

Fairclough, N. (2006b). Language and globalization. New York: Routledge.

Fairclough, N. (2009). Language and globalization. Semiotica 2009 (173), 317-342.

Fairclough, N. (2010). Critical discourse analysis: Critical study of language (2nd edn). Harlow: Longman.

Fairclough, N. (2014). What is CDA? Language and power twenty-five years on. Retrieved from https://www.academia.edu/8429277/What_is_CDA_Language_and_Power_ twenty-five_years_on

Fairclough, N. \& Graham, P. (2002). Marx as a critical discourse analyst: The genesis of a critical method and its relevance to the critique of global capital. Sociolinguistics Studies, 3(1), 1-56. Retrieved from file: ///C:/Users/nadir/Downloads/graham_29764\%20 (1).pdf

Fairclough, N., Graham, P., Lemke, J.L. \& Wodak, R. (2004). Introduction. Critical Discourse Studies, 1(1), 1-6.

Falk, I. (1994). The making of policy: Media discourse conversations. Discourse: Studies in the Cultural Politics of Education, 15(2), 1-12.

Feder, E.K. (2011). Power/knowledge. In D. Taylor (Ed.), Michel Foucault: Key concepts (pp. 55-68). Durham: Acumen.

Fong, L. (1979, 31 March). All 'ayes' for Goh report: Two amendments accepted. The Straits Times. Retrieved from http://eresources.nlb.gov.sg/newspapers/Digitised/Arti cle/straitstimes19790331-1.2.5.aspx

Foucault, M. (1967). Madness and civilization: A history of insanity in the Age of Reason (R. Howard, Trans.). London: Tavistock.

Foucault, M. (1972). The archaeology of knowledge; and The discourse on language. New York: Pantheon Monographs.

Foucault, M. (1973). The order of things: An archaeology of the human sciences. New York: Vintage Monographs.

Foucault, M. (1977). Discipline and punish: The birth of the prison (A. Sheridan, Trans.). London: Allen Lane.

Foucault, M. (1980). Power/knowledge: Selected interviews and other writings 1972-1977. C. Gordon, Ed. (C. Gordon, L. Marshall, J.K. Mepham \& K. Soper, Trans.). Brighton: Harvester Press.

Foucault, M. (1981a). The history of sexuality. An introduction (Vol. 1). (R. Hurley, Trans.). Harmondsworth: Penguin. 
Foucault, M. (1981b). The history of sexuality. The use of pleasure (Vol. 2). (R. Hurley, Trans.). Harmondsworth: Penguin.

Foucault, M. (1981c). The history of sexuality: The care of the self (Vol. 3). (R. Hurley, Trans.). Harmondsworth: Penguin.

Foucault, M. (1982a). The subject and power. Critical Inquiry, 8(4), 777-795.

Foucault, M. (1982b). This is not a pipe (J. Harkness, Trans. and Ed.). Berkeley: University of California Press. Retrieved from http://monoskop.org/images/9/99/Foucault_ Michel_This_Is_Not_a_Pipe.pdf

Foucault, M. (1984a). The ethic of the care for the self as a practice of freedom. An interview with Michael Foucault. (J.D. Gauthier, Trans.). Philosophy and Social Criticism, 12 (2-3), 112-131.

Foucault, M. (1984b). Foucault. Retrieved from http://foucault.info/foucault/biography. html

Foucault, M. (1986). The Foucault reader. P. Rabinow (Ed.). Harmondsworth: Penguin.

Foucault, M. (1991a). Questions of method. In G. Burchell, C. Gordon \& P. Miller (Eds.), The Foucault effect: Studies in governmentality: With two lectures and an interview with Michel Foucault (pp. 73-86). Chicago: University of Chicago Press.

Foucault, M. (1991b). Politics and the study of discourse. In G. Burchell, C. Gordon \& P. Miller (Eds.), The Foucault effect: Studies in governmentality: With two lectures and an interview with Michel Foucault (pp. 53-72). Chicago: University of Chicago Press.

Foucault, M. (1991c). Governmentality. In G. Burchell, C. Gordon \& P. Miller (Eds.), The Foucault effect: Studies in governmentality: With two lectures and an interview with Michel Foucault (pp. 87-104). Chicago: University of Chicago Press.

Foucault, M. (1994). On the genealogy of ethics: An overview of work in progress. In H. Dreyfus \& P. Rabinow (Eds.), Michel Foucault: Beyond structuralism and hermenentics (pp. 253-280). Chicago: University of Chicago Press.

Foucault, M. (1995). Discipline and punish: The birth of the prison (2nd edn). (A. Sheridan, Trans.). New York: Vintage.

Foucault, M. (1997). Ethics: Subjectivity and truth. New York: New Press.

Foucault, M. (1998). Essential works of Foucault, 1959-1989, Volume 1: Ethics: Subjectivity and truth. New York: New Press.

Foucault, M. (2001). The hermenentics of the subject: Lectures at the Collège de France, 1981-1982. [L'hermeneutique du sujet. Cours au Collège de France, 1981-1982]. Paris: Gallimard Seuil.

Foucault, M. (2002). Archaeology of knowledge. New York: Routledge.

Foucault, M. (2003). The essential Foucault: Selections from essential works of Foucault, 1954-1984. P. Rabinow \& N. Rose (Eds.). New York: New Press.

Foucault, M. (2005). The discourse on language and 'Truth and Power'. In J. Medina \& W. David (Eds.), Truth: Engagements across philosophical traditions. Introduction (pp. 315-335). Oxford: Blackwell.

Fox, M. (2002, 25 January). Michael Young, 86, scholar, coined, mocked 'meritocracy'. New York Times. Retrieved from https://www.nytimes.com/2002/01/25/world/m ichael-young-86-scholar-coined-mocked-meritocracy-html

Fowler, R. (1991). Language in the news: Discourse and ideology in the press. London: Routledge.

Fraser, N. (1981). Foucault on modern power: Empirical insights and normative conclusions. PRAXIS International (3), 272-287.

Fraser, N. (1995). From redistribution to recognition? Dilemmas of justice in a 'postsocialist' age. New Left Review (212), 68-93. 
Gale, T. (2001). Critical policy sociology: Historiography, archaeology and genealogy as methods of policy analysis. Journal of Education policy, 16(5), 379-393.

Garcia-Perez, D. (2012). Dismantling contemporary deficit thinking: Educational thought and practice [Review of R.R. Valencia, Dismantling contemporary deficit thinking: Educational thought and practice], International Journal of Educational Psychology, 1(3), 278-279.

Garrity, Z. (2010). Discourse analysis, Foucault and social work research: Identifying some methodological complexities. Journal of Social Work, 10(2), 193-210.

Gaventa, J. (2003). Foucault: Power is everywhere. Retrieved from www.powercube.net/ other-forms-of-power/foucault-power-is-everywhere/

General information. (n.d.). Retrieved from https://www.seab.gov.sg/pages/nationa IExaminations/PSLE/general_information.asp

Goh and his team get down to the task. (1978, 20 August). The Straits Times. Retrieved from http://eresources.nlb.gov.sg/newspapers/Digitised/Article/straitstimes19780820-1.2.3. aspx

Goh, C.T. (2016). Singapore faces income inequality, social cohesion challenges. Channel NewsAsia, 21 April 2015. Accessed 15 June 2016. www.channelnewsasia.com/news/ singapore/singapore-faces-income/2718188.html

Goh, C.B. \& Gopinathan, S. (2008). The development of education in Singapore since 1965. In S.K. Lee, C.B. Goh, B. Fredriksen \& J.P. Tan (Eds.), Toward a better future: Education and training for economic development in Singapore since 1965 (pp. 12-39). Washington, DC: The World Bank.

Gopinathan, S. (1996). Globalisation, the state and education policy in Singapore. Asia Pacific Journal of Education, 16(1), 74-87.

Gopinathan, S. (1999). Preparing for the next rung: Economic restructuring and educational reform in Singapore. Journal of Education and Work, 12(3), 295-308.

Gopinathan, S. (2006). Preparing for the next rung: Economic restructuring and educational reform in Singapore. Journal of Education and Work, 12(3), 296-308.

Gopinathan, S. (2007). Globalisation, the Singapore developmental state and education policy: A thesis revisited. Globalisation, Societies and Education, 5(1), 53-70.

Graham, L.J. (2011). The product of text and 'Other' statements: Discourse analysis and the critical use of Foucault. Educational Philosophy and Theory, 43(6), 663-674.

Graham, P. \& Paulsen, N. (2002). Third-sector discourses and the future of (un)employment: Skilled labour, new technologies and the meaning of work. Text, 22(3), 443-467.

Graham, P. (1999). Critical systems theory: A political economy of language, thought, and technology. Communication Research, 26(4), 482-507.

Graham, P. (2000). Hypercapitalism: A political economy of informational idealism. New media and Society, 2(2), 131-156.

Graham, P. (2001a). Space: Irrealis objects in technology policy and their role in a new political economy. Discourse and Society, 12(6), 761-788.

Graham, P. (2001b). Hypercapitalism: An investigation into the relationship between language, new media, and social perceptions of value (doctoral dissertation). Queensland University of Technology. Australia.

Graham, P. (2002). Predication and propagation: A method for analysing evaluative meanings in technology policy. Text 22(2), 227-268.

Graham, P. (2005). Analysing policy values in a knowledge economy. In D. Rooney, G. Hearn \& A. Ninan (Eds.), Handmonograph on the knowledge economy (pp. 118-128). Northampton: Edward Elgar. 
Graham, P. (2007). Critical discourse analysis and evaluative meaning: Interdisciplinary as a critical turn. In R. Wodak \& W. Gilbert (Eds.), Critical discourse analysis: Theory and interdisciplinarity (pp. 110-129). London: Palgrave Macmillan.

Graham, P. \& Luke, A. (2011). Critical discourse analysis and political economy of communication: Understanding the new corporate order. Cultural Politics, 7(1), 103-132.

Graham, P. (2018). Ethics in critical discourse analysis. Critical Discourse Studies, 15(2), 186-203.

Hall, S. (2001). The work of representation. In M. Wetherell, S. Taylor \& S.J. Yates (Eds.), Discourse theory and practice: $A$ reader (pp. 72-81). London: Sage.

Halliday, M.A.K. (1994). An introduction to functional grammar (2nd edn). London: Arnold.

Hamilton, M. \& Pitt, K. (2011). Changing policy discourses: Constructing literacy inequalities. International Journal of Educational Development, 31(6), 596-605.

Hao, X. (1996). The press and public trust: The case of Singapore. Asian Journal of Communication, 6(1), 111-123.

Hayek, F.A. (2007). The road to serfdom. London: University of Chicago Press.

Hegel, G.W.F. (1970). On art, religion, philosophy: Introductory lectures to the realm of the absolute spirit. J.G. Gray (Ed.). New York: Harper and Row.

Heidegger, M. (1961). On the essence of truth. Retrieved from http://aphelis.net/wp -content/uploads/2011/02/Martin-Heidegger-On-the-Essence-of-Truth.pdf

Heidegger, M. (2003a). The phenomenological method of the investigation (1972). (J. Stambaugh, Trans.). In Manfred Stassen (Ed.), Philosophical and political writings (pp. 57-69). New York: Continuum.

Heidegger, M. (2003b). Philosophy of language and poetry: Understanding, interpretation, discourse, language, idle talk (1927) . (J. Stambaugh, Trans.). In Manfred Stassen (Ed.), Philosophical and political writings (pp. 236-264). New York: Continuum.

Heidegger, M. (2003c). The question of being. (Letter to Ernst Junger 'Concerning "The Line"') (1955). (W. Kluback \& J.T. Wilde, Trans.). In Manfred Stassen (Ed.), Philosophical and political writings (pp 120-151). New York: Continuum.

Heidegger, M. (2005). On the essence of truth. In J. Medina \& W. David (Eds.), Truth: Engagements across philosophical traditions. Introduction (pp. 235-260). Oxford: Blackwell.

Heng, S.K. (2012). Prepared remarks for Mr Heng Swee Keat, Minister for Education, on "Education for competitiveness and growth" at the Singapore conference in Washington D.C., USA, on Wednesday, 8 February 2012. Retrieved from www.moe.gov.sg/media/ speeches $/ 2012 / 02 / 08 /$ speech-by-mr-heng-swee-keat-at-the-singapore-conference-wa shington-dc-usa.php.

Heng, S.K. (2014). FY 2014 Committee of Supply debate: 1st reply by Mr Heng Swee Keat, Minister for Education: Bringing out the best in every child. Retrieved from www. moe.gov.sg/media/speeches/2014/03/07/first-reply-by-mr-heng-swee-keat-bringingout-the-best-in-every-child.php

Hume, D. (1739). A treatise of human nature: Being An attempt to introduce the experimental method of reasoning into moral subjects. Retrieved from https://people.rit.edu/ wlrgsh/HumeTreatise.pdf

Ismail, M. \& Tan, A.L. (2005). Voices from the normal technical world: An ethnographic study of low-track students in Singapore. Proceedings of the Redesigning Pedagogy: Research, Policy, Practice conference, Singapore, May-June 2005. https://repository. nie.edu.sg/bitstream/10497/214/1/2005v4.pdf

Jessop, B. (2004). Critical semiotic analysis and cultural political economy. Critical Discourse Studies, 1(2), 159-174. 
Kincheloe, J.L. (2001). Describing the bricolage: Conceptualizing a new rigour in qualitative research. Qualitative Inquiry, 7(6), 679-692.

Klein, K.J. \& Kozlowski, S.W.J. (2000). From micro to meso: Critical steps in conceptualizing and conducting multilevel research. Organizational Research Methods, 3(3), 211-236.

Krishnamurti, J. (1978a). The impossible question. New York: Penguin.

Krishnamurti, J. (1978b). Truth and actuality. San Francisco: Harper \& Row.

Krishnamurti, J. (2005). Inward revolution: Bringing about radical change in the world. R. Mckoy (Ed.). Boston: Shambhala.

Krishnamurti, J. \& Bohm, D. (2014). The ending of time: Where philosophy and physics meet. New York: HarperCollins.

Lamont, Michèle (2012). Toward a comparative sociology of valuation and evaluation. Annual Review of Sociology, 38(21), 201-221.

Lee, K.Y. (2011). Hard truths to keep Singapore going. Singapore: Singapore Press Holdings.

Lee, N. (2004). Foreword. In D. Bohm, On dialogue (pp. xv-xxvii). Routledge Classics. London and New York: Routledge.

Lee, S.K., Goh, C.B., Fredriksen, B. \& Tan, J.P. (Eds.) (2008). Toward a better future: Education and training for economic development in Singapore since 1965 (pp. 39-68). Washington DC: The World Bank.

Lemke, J.L. (1995). Textual politics: Discourse and social dynamics. London: Taylor \& Francis.

Lemke, J.L. (1998). Resources for attitudinal meaning: Evaluative orientations in text semantics. Functions of Language, 5(1), 33-56.

Lemke, T. (2001). The birth of 'bio-politics': Michel Foucault's lecture at the Collège de France on neo-liberal governmentality. Economy and Society, 30(2), 190-207.

Liasidou, A. (2008). Critical discourse analysis and inclusive educational policies: The power to exclude. Journal of Education Policy, 23(5), 483-500.

Lim, L. (2013). Meritocracy, elitism, and egalitarianism: A preliminary and provisional assessment of Singapore's primary education review. Asia Pacific Journal of Education, 33(1), 1-14.

Loy, D.R. (1997). The religion of the market. Journal of the American Academy of Religion, 65(2), 275-290.

Luke, A. (1997). Critical discourse analysis. In L. Saha (Ed.), International encyclopaedia of the sociology of education (pp. 50-57). Oxford: Elsevier.

Luke, A. (2002). Beyond science and ideology critique: Developments in critical discourse analysis. Annual Review of Applied Linguistics, 22, 96-110.

Luke, A. (2009). Critical realism, policy, and educational research. In K. Ercikan \& W.M. Roth (Eds.), Generalizing from educational research: Beyond qualitative and quantitative polarization (pp. 173-200). New York: Routledge.

Markula, P. (2004). 'Tuning into one's self': Foucault's technologies of the self and mindful fitness. Sociology of Sport Journal, 21(3), 302-321.

Marshall, J. (1996). Michel Foucault: Personal autonomy and education. London: Kluwer.

Martin, J.R. \& Rose, D. (2007). Working with discourse: Meaning beyond the class (2nd edn). New York: Continuum.

Martin, J.T. (2000). Beyond exchange: Appraisal systems in English. In S. Hunston \& G. Thompson (Eds.), Evaluation in text: Authorial stance and the construction of discourse (pp. 142-175). New York: Oxford University Press. 
Marx, K. (1976). Capital: A critique of political economy. Vol. I (B. Fowkes, Trans.). London: Penguin.

Maté, G. (2012, 12 August). What promotes positive health. Retrieved from https:// www.youtube.com/watch?v=rYbeyU3pQvI

Maté, G. (2019, 14 June). Dr Gabor Maté on childhood trauma, the real cause of anxiety, our 'insane' culture and Ayahuasca. Retrieved from https://www.youtube.com/watch? $\mathrm{v}=\mathrm{e} 7 \mathrm{pV} 0 I P W U I I$

Mautner, G. (2009). Checks and balances: How corpus linguistics can contribute to CDA. In R. Wodak and M. Meyer (Eds.), Methods of critical discourse analysis (2nd edn) (pp. 122-143). Los Angeles: Sage.

Mauzy, D.K. \& Milne, R.S. (2002). Singapore politics under the People's Action Party. London: Routledge.

May, T. (1993). Between genealogy and epistemology: Psychology, politics, and knowledge in the thought of Michel Foucault. University Park PA: Pennsylvania State University Press.

Mckee, K. (2009). Post-Foucauldian governmentality: What does it offer critical social policy analysis? Critical Social Policy, 29(3), 465-486.

McKerrow, R. (n.d.). Foucault and surrealism of truth. Retrieved from www.ohio.edu/ People/mckerrow/foucault.pdf

Medina, J. \& Wood, D. (Eds.) (2005). Truth: Engagements across philosophical traditions. Introduction. Oxford: Blackwell.

MOE (Ministry of Education). (1987). Towards excellence in schools. A report submitted to the Ministry for Education. Singapore: Ministry of Education.

MOE (Ministry of Education). (1979a). Report on the Ministry of Education 1978, prepared by Goh Keng Swee and the Education Study Team. Singapore: Singapore National Printers.

MOE (Ministry of Education). (1979b). Curriculum development in Singapore. A Brief Review 1979, created by Robert W. Morris. Singapore: Ministry of Education.

MOE (Ministry of Education). (1991a). Improving primary school education: Report of the Review Committee. Singapore: Ministry of Education.

MOE (Ministry of Education). (1991b). Upgrading vocational training/Vocational and Industrial Training Board. Singapore: The Board.

MOE (Ministry of Education). (1997). Performance by ethnic group. Retrieved from www. moe.gov.sg/media/press/1997/pr02397.htm

MOE (Ministry of Education). (2002). Report of the Junior College/Upper Secondary Education Review Committee. Retrieved from http://www3.moe.edu.sg/jcreview/JC_ Upp_Sec_Review_Report.pdf

MOE (Ministry of Education). (2006). Report of the Polytechnic-School Review Committee. Retrieved from http://www3.moe.edu.sg/corporate/pdf/psrc-report.pdf

MOE (Ministry of Education). (2008a). Report of the Committee on the Expansion of the University Sector. Greater choice, more room to excel: Final report. Retrieved from www. moe.gov.sg/media/press/files/2008/08/ceus-final-report-and-exec-summary.pdf

MOE (Ministry of Education). (2008b). Enhanced programmes by Special Assistance Plan schools to enrich students' learning of Chinese language and values. Retrieved from www. moe.gov.sg/media/press/2008/02/enhanced-programmes-by-special.php\#annex-b.

MOE (Ministry of Education). (2012a). Report of the Committee on University Education Pathways Beyond 2015 (CUEP). Greater diversity, more opportunities: Final report. August 2012. Retrieved from www.moe.gov.sg/media/press/files/2012/08/cuep-rep ort-greater-diversity-more-opportunities.pdf.

MOE (Ministry of Education). (2012b). Education in Singapore. Retrieved from www. moe.edu.sg/about/files/moe-corporate-brochure.pdf 
MOE (Ministry of Education). (2012c). Press Release: Performance by ethnic group in national examinations 2002-2011. Retrieved from www.moe.gov.sg/media/press/ 2012/10/performance-by-ethnic-group-in.php

Normal course curriculum (n.d.). Retrieved from www.moe.gov.sg/education/secondary/ normal/

Mulderrig, J. (2003). Consuming education: A critical discourse analysis of social actors in New Labour's education policy. Journal of Critical Education Policy Studies, 1(1), 96-123.

Mulderrig, J. (2007). Textual strategies of representation and legitimation in New Labour policy discourse. In A. Green, G. Rikowski \& H. Raduntz (Eds.), Renewing dialogues in Marxism and education: Openings (pp. 135-150). Basingstoke: Palgrave Macmillan.

Mulderrig, J. (2008). Using keywords analysis in CDA: Evolving discourses of the knowledge economy in education. In B. Jessop, N. Fairclough \& R. Wodak (Eds.), Education and the knowledge-based economy in Europe (pp. 149-170). Rotterdam: Sense Publishers.

Mulderrig, J. (2009). The language of education policy: From Thatcher to Blair. Saarbrucken, Germany: VDM Verlag.

Mulderrig, J. (2011a). The grammar of governance. Critical Discourse Studies, 8(1), $45-68$.

Mulderrig, J. (2011b). Manufacturing consent: A corpus-based critical discourse analysis of New Labour's educational governance. Educational Philosophy and Theory, 43(6), 562-578.

Mulderrig, J. (2012). The hegemony of inclusion: A corpus-based critical discourse analysis of deixis in education policy. Discourse and Society, 23(6), 701-728.

Mulderrig, J. (2014). 'Enabling' participatory governance in education: A corpus-based critical analysis of policy in the United Kingdom. In P. Smyers, D. Bridges, N. Burbules \& M. Griffiths (Eds.), International handbook of interpretation in educational research. Springer International Handbooks of Education, 1 (pp. 441-470). Dordrecht: Springer. ISBN ISBN: 9789401792813.

Nasr, S.H. (1996). Mulla Sadra: His teachings. In S.H. Nasr \& O. Leaman (Eds.), History of Islamic philosophy (pp. 643-662). London: Routledge.

$\mathrm{Ng}$, D.F.S. (2008c). Strategic management of educational development in Singapore (1965-2005). In S.K. Lee, C.B. Goh, B. Fredriksen \& J.P. Tan (Eds.), Toward a better future: Education and training for economic development in Singapore since 1965 (pp. 39-68). Washington DC: The World Bank.

$\mathrm{Ng}$, E.H. (2008). Educating the next generation. Speech by Dr Ng Eng Hen, Minister for Education and Second Minister for Defence, at the 4th Anniversary Public Lecture at the Lee Kuan Yew School of Public Policy, 14 August. Retrieved from www.moe.gov. sg/media/speeches/2008/08/14/speech-by-dr-ng-eng-hen-at-the-10.php

Ng, I.Y.H. (2011). Growing worry of social mobility. The Straits Times Review, p. A25. Retrieved from http://newshub.nus.edu.sg/news/1102/PDF/IMMOBILITY-st-16feb-pA25.pdf

$\mathrm{Ng}$, I.Y.H. (2013). The political economy of intergenerational income mobility in Singapore. International Journal of Social Welfare, 22, 207-218.

$\mathrm{Ng}$, P.T. (2008b). The phases and paradoxes of educational quality assurance. Quality Assurance in Education, 16(2), 112-125.

Nicoll, K. (1998). 'Fixing' the 'Facts': Flexible learning as policy intervention. Higher Education Research and Development, 17(3), 291-304.

Nicoll, K. (2006). Flexibility and lifelong learning: Policy, discourse and politics. New York: Routledge.

Nietzsche, F. (1909). Human, all too human: A monograph for free spirits. (H. Zimmern, Trans.). London: Allen \& Unwin. 
Nietzsche, F. (1924). The antichrist. (H.L. Mencken, Trans.). New York: Vail-Ballou Press. Nietzsche, F. (1967a). The will to power. (W. Kaufmann \& R.J. Hollingdale, Trans.). New York: Random House.

Nietzsche, F. (1967b). On the genealogy of morals. [and] Ecce homo. (W. Kaufmann \& R.J. Hollingdale, Trans.). New York: Vintage.

Nietzsche, F. (1974). The gay science: With a prelude in rhymes and an appendix of songs. (W. Kaufmann, Trans.). New York: Random House.

Nietzsche, F. (1979). On truth and lies in the nonmoral sense. In D. Breazeale (Ed.), Philosophy and truth: Selections from Nietzsche's notemonographs of the early 1870s (pp. 79-97). Atlantic Highlands, NJ: Humanities Press.

Nietzsche, F. (1989). Beyond good and evil. New York: Random House.

Oakes, J. (2005). Keeping track: How schools structure inequality. New Haven, CT: Yale University Press.

OECD. (2011). Perspectives on Global Development 2012: Social cohesion in a shifting world. Paris: OECD Publishing. doi:10.1787/persp_glob_dev-2012-en

Olssen, M. (2006). Understanding the mechanisms of neo-liberal control: Lifelong learning, flexibility and knowledge capitalism. International Journal of Lifelong Education, 25 (3), 213-230.

Ong, Y.K. (2018a). MOE FY2018 Committee of Supply debate response by Minister for Education (Higher Education and Skills) on 5 March 2018. Retrieved from https:// www.moe.gov.sg/news/speeches/moe-fy2018-committee-of-supply-debate-responseby-minister-for-education-higher-education-and-skills-mr-ong-ye-kung

Ong, Y.K. (2018b). Opening address by Mr Ong Ye Kung, Minister for Education, at the Schools Work Plan Seminar on 28 September 2018. Retrieved from https://www.moe. gov. $\mathrm{sg} /$ news/speeches/opening-address-by-mr-ong-ye-kung-minister-for-education-a t-the-schools-work-plan-seminar

Ong, Y.K. (2019). Speech by Minister for Education Mr Ong Ye Kung, at the 2019 Raffles Institution Founder's Day, on 27 July 2019. Retrieved 20 August 2019 from https:// www.moe.gov.sg/news/speeches/speech-by-minister-for-education-mr-ong-ye-kung-atthe-2019-raffles-institution-founders-day

Pennycook, A. (2001). Critical applied linguistics: A critical introduction. Mahwah, NJ: Lawrence Erlbaum.

Peters, S.J. (2007). 'Education for all?' A historical analysis of international inclusive education policy and individuals with disabilities. Journal of Disability Policy Studies, 18(2), 98-108.

Poole, B. (2010). Commitment and criticality: Fairclough's Critical Discourse Analysis evaluated. International Journal of Applied Linguistics, 20(2), 137-155.

Quah, J.S.T. (1984). The public policy-making process in Singapore. Asian Journal of Public Administration, 6(2), 108-126.

Rahim, L.Z. (1998). The Singapore dilemma: The political and educational marginality of the Malay community. New York: Oxford University Press.

Rajah, I. (2018). Parliamentary motion 'Education For Our Future' response by 2nd Minister for Education, Ms Indranee Rajah on 11 July 2018. Retrieved 14 October 2019 from https://www.moe.gov.sg/news/speeches/parliamentary-motion-educationfor-our-future-response-by-2nd-minister-for-education-ms-indranee-rajah

Rajah, I. (2019). NUS Social Service Research Centre conference 'Working with Low-Income Families through the Life Course: Challenges to Social Services'. Keynote speech by second Minister for Education, Ms Indranee Rajah, on 18 July 2019. Retrieved 20 August 2019 from https://www.moe.gov.sg/news/speeches/nus-social-service-research-centre-confer 
ence-working-with-low-income-families-through-the-life-course-challenges-to-social-servi ces-keynote-speech-by-second-minister-for-education-ms-indranee-rajah

Raman, P.M. (1978, 17 August). New team to study education. Group to be led by Dr. Goh. The Straits Times. Retrieved from http://eresources.nlb.gov.sg/newspapers/Digi tised/Article/straitstimes19780817-1.2.3.aspx

Rawlinson, M.C. (1987). Foucault's strategy: Knowledge, power, and the specificity of truth. Journal of Medicine and Philosophy, 12(4), 371-395.

Rogers, R. (2004a). Critical approaches to discourse analysis in educational research. In R. Rogers (Ed.), An introduction to critical discourse analysis in education (pp. 1-20). Mahwah, NJ: Lawrence Erlbaum Associates.

Rogers, R. (2004b). A critical discourse analysis of literate identities across contexts: Alignment and conflict. In R. Rogers (Ed.), An introduction to critical discourse analysis in education (pp. 51-78). Mahwah, NJ: Lawrence Erlbaum Associates.

Rogers, R., Malancharuvil-Berkes, E.; Mosley, M., Hui, D. \& Joseph, G.O. (2005). Critical discourse analysis in education: A review of the literature. Review of Educational Research, 75(3), 365-416.

Rooney, D. (2005). Knowledge, economy, technology and society: The politics of discourse . Telematics and Informatics, 22(4), 405-422.

Rouse, J. (2005). Power/knowledge. In G. Gutting (Ed.), The Cambridge companion to Foucault (2nd edn) (pp. 95-122). New York and Cambridge: Cambridge University Press.

Saarinen, T. (2008). Position of text and discourse analysis in higher education policy research. Studies in Higher Education, 33(6), 719-728.

Sandberg, J. \& Alvesson, M. (2011). Ways of constructing research questions: Gap-spotting or problematization? Oragnization, 18(1), 23-44.

Sartre, J-P. (1985). Existentialism and human emotions. New York: Citadel Press.

Satz, D. (2007). Equality, adequacy, and education for citizenship. Ethics, 117(4), 623-648.

Scheurich, J.J. (1997). Research method in the postmodern. Brighton: Falmer Press.

Schopenhauer, A. (1907). The world as will and idea (Vol. 2). (R.B. Haldane \& J. Kemp, Trans.). London: Kegan Paul, Trench, Trubner.

Secondary education (n.d.) Retrieved from www.moe.gov.sg/education/secondary/

Sen, A. (1992). Inequality reexamined. New York: Russell Sage Foundation.

Sen, A. (2000). Merit and justice. In K. Arrow, S. Bowles \& S. Durlauf (Eds.), Meritocracy and economic inequality (pp. 5-16). Princeton, NJ: Princeton University Press. Retrieved 8 August from http://assets.press.princeton.edu/chapters/s6818.pdf

Shanmugaratnam, T. (2003). Speech by Mr Tharman Shanmugaratnam. Acting Minister for Education, at the MOE work plan seminar at Ngee Ann Polytechnic on Thursday, 2 October 2003: The next phase in education: Innovation and Enterprise. Retrieved from www.moe.gov.sg/media/speeches/2003/sp20031002.htm

Shanmugaratnam, T. (2004). Schools: Refinements to primary school streaming; The Normal Course. Retrieved from www.moe.gov.sg/media/speeches/2004/sp20040318.htm

Shanmugaratnam, T. (2006). Speech by Mr Tharman Shanmugaratnam. Minister for Education, at the MOE work plan seminar 2006, on Thursday, 28 September 2006 at $10.00 \mathrm{am}$ at the Ngee Ann Polytechnic convention centre: More support for schoolbased initiatives. Ground-up initiatives, top-down support. Retrieved from www.moe. gov.sg/media/speeches/2006/sp20060928_print.htm

Sharpe, L. \& Gopinathan, S. (2002). After effectiveness: New directions in the Singapore school system? Journal of Education Policy, 17(2), 151-166. 
Smith, A. (1759 [2010]). The theory of moral sentiments. Retrieved from www.earlym oderntexts.com/authors/smith

Soon, T.W. (1988). Singapore's new education system. Education reform for national development. Singapore: Institute of Southeast Asian Studies.

Springer, S. (2012). Neoliberalism as discourse: Between Foucauldian political economy and Marxian poststructuralism. Critical Discourse Studies, 9(2), 133-147.

Tan, K.P. (2008). Meritocracy and elitism in a global city: Ideological shifts in Singapore. International Political Science Review, 29(1), 7-27.

Taylor, S. (2004). Researching educational policy and change in 'new times': Using critical discourse analysis. Journal of Education Policy, 19(4), 433-451.

Teo, C.H. (2002a). Education system caters to all abilities. The Straits Times, 22 May 2002. Retrieved from http://global.factiva.com.ezproxy.library.uq.edu.au/ha/default.aspx

Teo, C.H. (2002b). Meeting different needs. The Straits Times, 26 November 2002. Retrieved from http://global.factiva.com.ezproxy.library.uq.edu.au/ha/default.aspx

Thich Nhat Hanh. (2010). Together we are one: Honouring our diversity, celebrating our connection. California: Parallax Press.

Thomas, S. (2005). The construction of teacher identities in educational policy documents: A critical discourse analysis. Melbourne Studies in Education, 46(2), 25-44.

Thomas, S. (2009). Newspapers on education policy: Constructing an authoritative public voice on education. In R. Fitzgerald \& W. Housley (Eds.), Media policy and interaction (pp. 205-223). Burlington, VT: Ashgate Publishing.

Thompson, G. \& Hunston, S. (2000). Evaluation: An introduction. In G. Thompson \& S. Hunston (Eds.), Evaluation in text: Authorial stance and the construction of discourse (pp. 1-27). Oxford: Oxford University Press.

Trew, T. (1979). 'What the papers say': Linguistic variation and ideological difference. In R. Fowler, B. Hodge, G. Kress \& T. Trew (Eds.), Language and control (pp. 117-156). London: Routledge.

Valencia, R.R. (2010). Dismantling contemporary deficit thinking: Educational thought and practice], International Journal of Educational Psychology, 1(3), 278-279.

van Dijk, T.A. (1993). Principles of critical discourse analysis. Discourse and Society, 4(2), 249-283.

van Dijk, T.A. (2001). Multidisciplinary CDA: A plea for diversity. In R. Wodak \& M. Meyer (Eds.), Methods of critical discourse analysis (1st edn) (pp. 95-121). London: Sage.

van Dijk, T.A. (2003). Critical discourse analysis. In D. Schiffrin, D. Tannen \& H.E. Hamilton (Eds.), The handbook of critical discourse analysis (pp. 352-371). Oxford: Blackwell.

van Leeuwen, T. (1995). Representing social action. Discourse and Society, 6(1), 81-106.

van Leeuwen, T. (1996). The representation of social actors. In C.R. Caldas-Coulthard \& M. Coulthard (Eds.), Texts and practices: Readings in critical discourse analysis (pp. 3271). London: Routledge.

van Leeuwen, T. (2008). Discourse and practice: New tools for critical discourse analysis. New York: Oxford University Press.

Verschueren, J. (1999). Understanding pragmatics. New York: Arnold.

Walsh, N.D. (2005). What God wants: A compelling answer to humanity's biggest question. New York: Atria.

Walsh, N.D. (2013). What God said: The 25 core messages of conversations with God that will change your life and the world. New York: Berkley.

Walshaw, M. (2007). Working with Foucault in education. Rotterdam: Sense Publishers.

Watts, A.W. (1951). The wisdom of insecurity. New York: Pantheon. 
Wodak, R. (1999). Critical discourse analysis at the end of the 20th century. Research on Language and Social Interaction, 32(1\&2), 185-193.

Wodak, R. (2001). The discourse-historical approach. In R. Wodak \& M. Meyer (Eds.), Methods of critical discourse analysis (pp. 63-95). London: Sage.

Wong. A. (2000). Keynote address by Dr Aline Wong, Senior Minister of State for Education, Ministry of Education, Singapore, at the International Baccalaureate (IB) Asia-Pacific 16th annual regional conference on curriculum, assessment and cultural equity to be held on Friday, 24 November 2000, at 9.15 am at the Raffles City Convention Centre: Education in a multicultural setting - the Singapore experience. Retrieved from www.moe.gov.sg/media/sp eeches $/ 2000 / \mathrm{sp} 24112000$.htm

Young, M.D. (1958). The rise of meritocracy. London: Thames and Hudson.

Zelizer, V.A. (1979). Morals and markets: The development of life insurance in the United States. New York: Columbia University Press. 